\title{
An extension of the Svecofennian orogenic province into NE Poland: Evidence from geochemistry and detrital zircon from Paleoproterozoic paragneisses
}

\author{
Ian S. Williams ${ }^{\mathrm{a}, *}$, Ewa Krzemińska ${ }^{\mathrm{b}}$, Janina Wiszniewska ${ }^{\mathrm{b}}$ \\ a Research School of Earth Sciences, The Australian National University, Canberra, ACT 0200, Australia \\ ${ }^{\mathrm{b}}$ Polish Geological Institute, ul. Rakowiecka 4, 00-975 Warszawa, Poland
}

\section{A R T I C L E I N F O}

\section{Article history:}

Received 12 October 2008

Received in revised form 23 April 2009

Accepted 27 April 2009

\section{Keywords:}

Precambrian basement

Poland

Trace element geochemistry

Detrital zircon age

Svecofennian metasediment

East European Craton

\begin{abstract}
A B S T R A C T
The Precambrian crystalline rocks of northern Poland are known only from deep drill cores. Drilling at Jastrzebna and Monki, in the Mazowsze Domain, NE Poland, has intersected a monotonous sequence of grey paragneisses superficially similar to the paragneisses of the Svecofennian Domain exposed in Sweden and Finland. Petrographically, geochemically and isotopically the rocks from the two regions are in fact almost the same. The Jastrzebna paragneiss is an immature metasediment characterised by depleted HREE and Y, indicative of derivation from a source dominated by TTG-type rocks. The Monki metasediment, in contrast, is more mature and chemically uniform, with a REE pattern very similar to average Post-Archean Australian Shale (PAAS). Both metasediments have La-Sc-Th compositions characteristic of active continental margin or continental arc settings. The detrital zircon populations in the two Polish metasediments have the same age distributions; a dominant Paleoproterozoic population at 2.1-1.9 Ga, a subordinate late Archean population at 2.9-2.7 Ga, and rare early Archean grains up to 3.4 Ga. Both samples have very few zircons in the age range 2.6-2.1 Ga. This age distribution is extremely similar to the age distributions of detrital zircon from Svecofennian metasediments exposed in Sweden and Finland. It is highly likely that the Polish metasediments are derived from the same source region as the 'classical' Svecofennian, and were deposited in the same basin or basin system. The ages of the detrital zircons do not match the ages of any known igneous rocks currently exposed in the Baltic Shield. However, they do match the ages of rocks within the Osnitsk-Mikashevichi Igneous Belt on the western margin of Sarmatia, plus Archean rocks of the adjacent Ukrainian Shield. It is likely that detritus eroded from this region at ca. $1.93-1.86 \mathrm{Ga}$, during a period of rapid uplift, was deposited in a continental marginal basin system adjacent to the Archean craton. The Polish metasediments were metamorphosed up to lower amphibolite facies at ca. $1.83 \mathrm{Ga}$.
\end{abstract}

(C) 2009 Elsevier B.V. All rights reserved.

\section{Introduction}

The Precambrian crystalline basement of NE Poland is completely covered by Phanerozoic sediments ranging in thickness from $500 \mathrm{~m}$ to ca. $5 \mathrm{~km}$. The basement is known only through drill cores from over 260 deep boreholes. Most of these (ca. 150) are located in the Mesoproterozoic Suwalki Anorthosite Massif and related Mazury Complex (MC) in far NE Poland (Fig. 1), and in the Podlasie region, close to the Belarus border. Only a few holes have been drilled in the Mazowsze Domain (Krzemińska and Wiszniewska, 2007), the large geophysically monotonous region between the Trans-European Suture Zone (TESZ) and the

\footnotetext{
* Corresponding author.

E-mail addresses: ian.williams@anu.edu.au (I.S. Williams) ewa.krzeminska@pgi.gov.pl (E. Krzemińska), janina.wiszniewska@pgi.gov.pl (J. Wiszniewska).
}

Belarus-Podlasie Granulite Belt (BPG; Taran and Bogdanova, 2003). The geological affinities of the basement in that region and the origin of the rocks therefore remain relatively unknown.

To the east of the Mazowsze Domain (MD), close to the borders with Lithuania and Belarus, the BPG is manifest as strong NNE-trending linear magnetic and gravity anomalies (Fig. 2). This belt, intensively sampled by drilling, consists mostly of Paleoproterozoic paragneisses and mafic orthogneisses. To the north, close to the border with Lithuania and the Kaliningrad area, is the Mesoproterozoic Mazury Complex, a major EWtrending anorthosite-mangerite-charnockite-granite (AMCG) belt (Wiszniewska et al., 2002). Sparse drilling to the west and south also has intersected Paleoproterozoic basement orthogneisses but, because the depth to the basement increases rapidly towards the TESZ, their petrogenesis and extent have yet to be explored.

Previous work on the Mazowsze Domain has been focused on the isolated geophysical anomalies in the Lomza, Elk, Pisz and Tajno regions. These anomalies represent localised igneous complexes of 


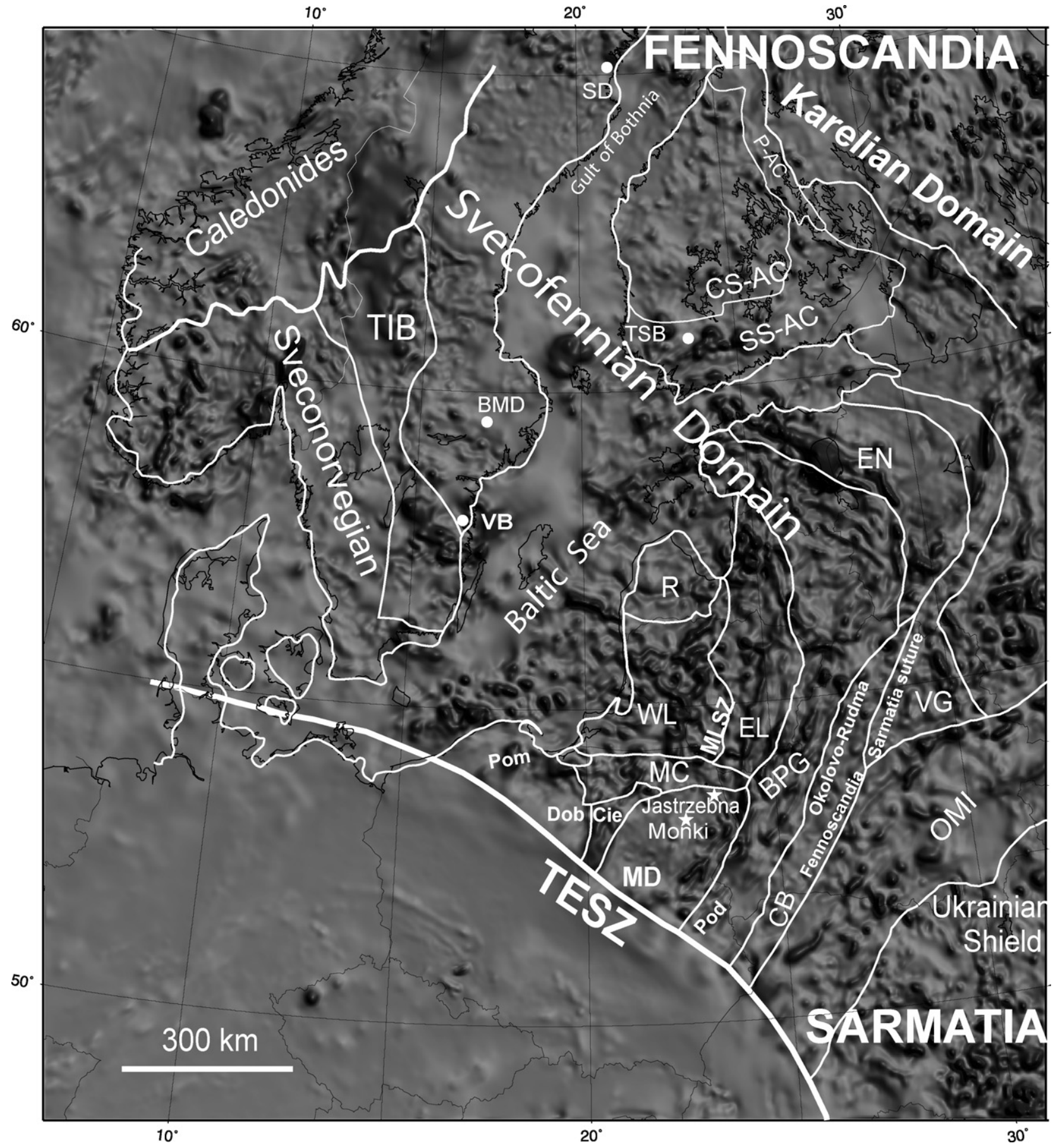

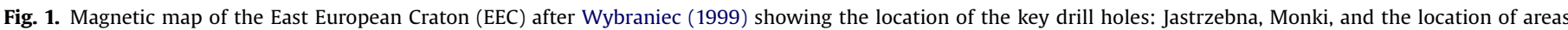

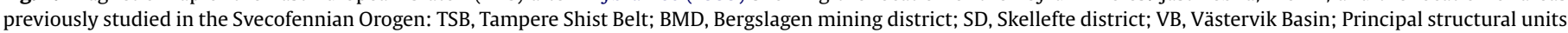

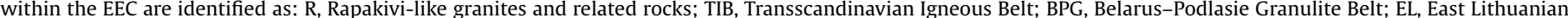

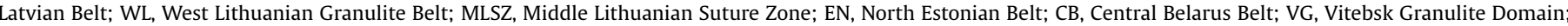

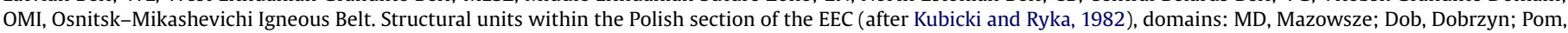

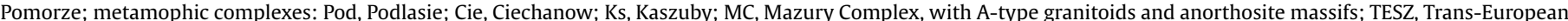

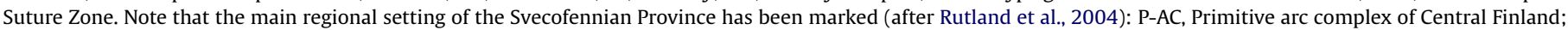
CS-AC, Accretionary arc complex of central and western Finland; SS-AC, Accretionary arc complex of southern Finland.

different ages. The Lomza suite consists of late Paleoproterozoic amphibolites and orthogneisses, possibly representing part of a ca. 1.8 Ga volcanic arc (Krzemińska et al., 2005). The Elk, Pisz and Tajno massifs are Early Carboniferous ultramafic, alkaline and carbonatite intrusions, possibly related to reactivation of an intracontinental rift zone within Baltica (Torsvik et al., 1996; Krzemińska et al., 2006a).

The host rocks to the igneous complexes are high-grade paragneisses intersected only by drill holes at Jastrzebna and Monki
(Ryka, 1976; Wolkowicz, 1996). K-Ar biotite ages measured on the paragneisses and crosscutting pegmatites range from 2.6 to $1.3 \mathrm{Ga}$, leading to the suggestion that at least some of the rocks are Archean (Depciuch et al., 1975). This conclusion contrasts with the results of later Nd isotopic analyses, which consistently yielded Paleoproterozoic model ages of 2.2-2.0 Ga (Claesson and Ryka, 1999).

As part of a larger project focused on reconstruction of the crustal evolution of the Polish portion of the East European Craton 


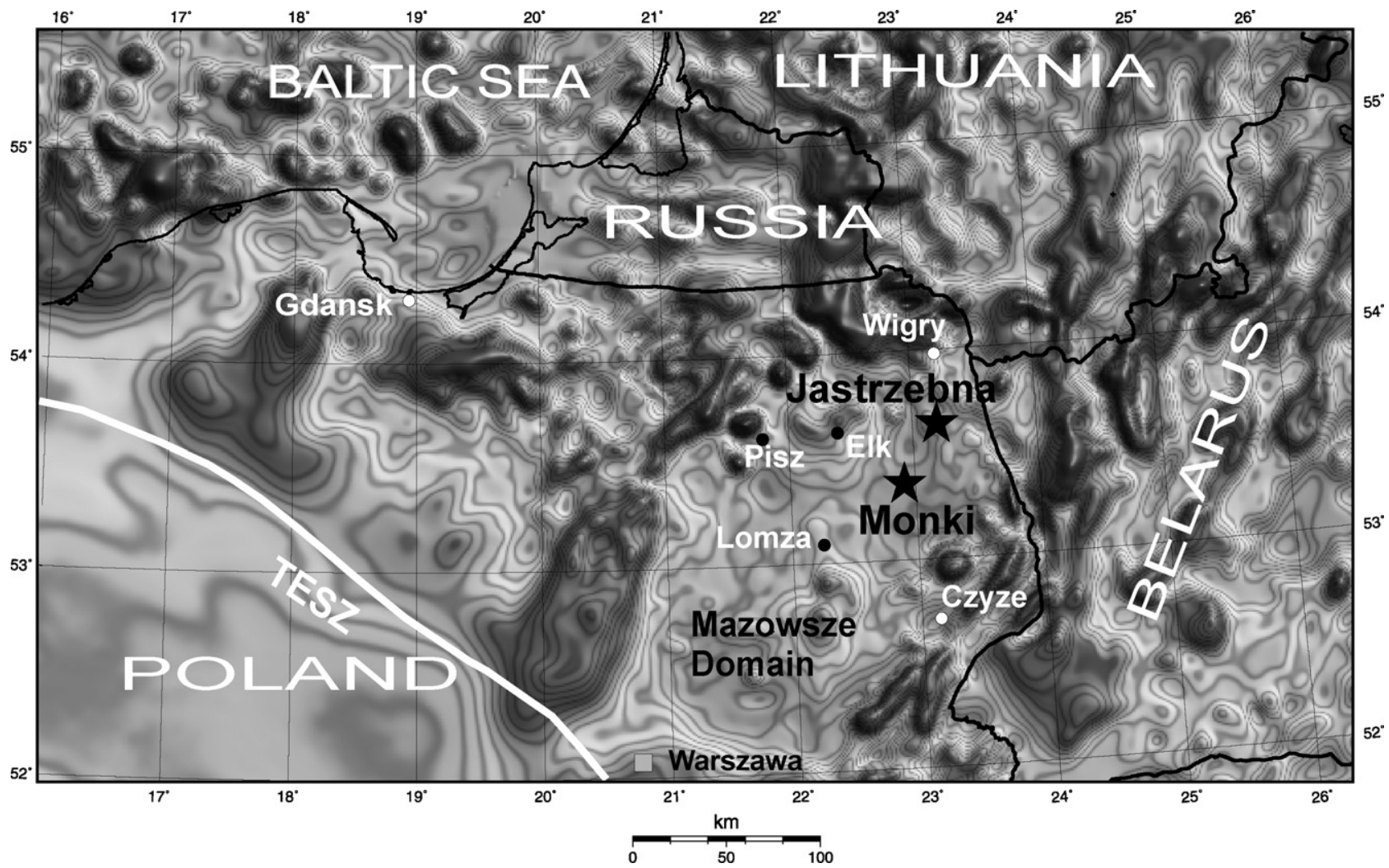

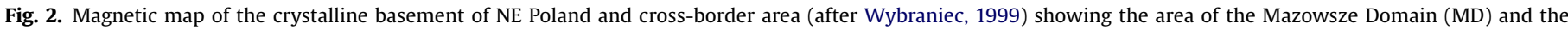
location of the sampling sites: Monki and Jastrzebna. The locations of the other drill holes (Czyze, Wigry, Gdansk) that also intersected metasediments, are shown.

(EEC), zircon and monazite from host paragneisses from Jastrzebna and Monki have been dated by SHRIMP U-Th-Pb with the objective of determining not only the age of the metasediments, but also their metamorphic history and possible provenance.

\section{Regional geological setting}

Poland lies within the Fennoscandia Block, at the southwestern margin of the Precambrian EEC (Fennoscandia, Sarmatia and VolgoUralia; Gorbatschev and Bogdanova, 1993). This block is exposed in the northern regions of Norway, Sweden, Finland and western Russia, where it forms the Baltic Shield.

The Baltic Shield has been divided into several domains, the age of which decreases towards the southwest. The Archean Domain, in northeastern Fennoscandia, is composed of a granite-gneiss association with greenstone, paragneiss and granulite complexes. The crust in that region is thought to have formed mainly during a series of subduction/accretion and collision episodes (Slabunov et al., 2006 and references therein) at 3.10-2.95 Ga (Vodozero terrane), 2.88-2.82 Ga (Karelian and Murmansk Cratons), $2.82-2.75 \mathrm{Ga}$ (NE Karelian Craton, Belomorian mobile belt) and 2.75-2.65 Ga (zone between the Belomorian mobile belt and Karelian Craton). Possible early Archean rocks (3.55-3.30 Ga) have been identified amongst the high-grade Vodlozero gneisses of the Karelian Craton (Sergeyev et al., 1990; Lobach-Zuchenko et al., 1993), and trondhjemitic gneisses with zircon ages of 3.50-3.11 Ga have been reported from the western margin of Karelian Craton in Finland (Mutanen and Huhma, 2003).

The Svecofennian Domain, in central Fennoscandia, developed at the margin of the Karelian Craton, mainly during five orogenic stages (ca. 1.92-1.77 Ga) collectively called the Svecofennian Orogeny (Korja et al., 2006 and references therein). The domain is dominated by metasediments and $1.90-1.78$ Ga granitoids and vol- canic rocks (Huhma, 1986; Gaal and Gorbatschev, 1987; Korja et al., 2006 and references therein). The metasediments were sourced predominantly from rocks of Archean (3.0-2.6 Ga) and Paleoproterozoic (2.1-1.9 Ga) age (Huhma et al., 1991; Claesson et al., 1993).

The Svecofennian Domain has been divided into three subprovinces (e.g. Lahtinen et al., 2002), the dominantly igneous Northern and Southern subprovinces, separated by a mostly marine sedimentary Central subprovince containing the Bothnian Basin (Hietanen, 1975; Nironen, 1997). The igneous rocks in the Northern and Southern subprovinces mostly have ages in the range $1.90-1.85 \mathrm{Ga}$, although rare volcanic rocks and granites up to $1.95 \mathrm{Ga}$ occur in northern Sweden (Korja et al., 2006). The igneous rocks have mostly been interpreted as the remains of volcanic arcs (e.g. Park, 1985; Lahtinen, 1994), but alternatively it has been proposed that the volcanism post-dated the accretion, metamorphism (at $1.92 \mathrm{Ga}$ ) and reworking of a large marginal basin (Rutland et al., 2004; Williams et al., 2008). The whole Svecofennian Domain was subject to late low-pressure metamorphism, its peak decreasing in age from ca. $1.88 \mathrm{Ga}$ in Finland to $1.85-1.75 \mathrm{Ga}$ in Sweden (Kilpeläinen et al., 1994; Lahtinen et al., 2002; Bergman et al., 2006; Skiöld and Rutland, 2006; Högdahl et al., 2008).

The meridional, predominantly bimodal Transscandinavian Igneous Belt (TIB) developed episodically along the southwestern margin of the Svecofennian Domain in the Late Paleoproterozoic (1.81-1.66 Ga), possibly in relation to an east-dipping subduction zone (Gorbatschev and Bogdanova, 1993; Gorbatschev, 2004; Högdahl et al., 2004; Åhäll and Connelly, 2008). Some granites in the TIB are broadly coeval with the Danopolonian Orogeny in SE Sweden, Bornholm, Lithuania and Poland (ca. $1.55 \mathrm{Ga}$; Bogdanova, 2001, 2005).

In turn, at the southwestern margin of the TIB, is the Sveconorwegian orogenic belt, high-grade marine sediments and igneous rocks, possibly including equivalents of the TIB, metamorphosed 
during a sequence of events over the period 1.2-0.9 Ga, the Sveconorwegian Orogeny (Möller et al., 2007 and references therein).

It has been proposed that during the Svecofennian Orogeny the Bothnian Basin or related basins extended from the area of presentday central Sweden east and southeast at least into southern Finland, and possibly as far south as Lithuania, Poland and Belarus, where the Precambrian basement is covered by Phanerozoic sediments (Puura and Huhma, 1993; Claesson et al., 1993; Bogdanova et al., 1994, 2006; Soesoo et al., 2004; Wiszniewska et al., 2006; Skridlaite et al., 2007). This possibility is strongly supported by geophysical observations. Geophysical studies show that bedrock gravity and magnetic features extend from SE Sweden under the Baltic Sea and into Estonia (Wybraniec, 1999). Magnetic trends in the Svecofennian of southern Finland also align with trends in the northern end of the BPG, which extends nearly $1000 \mathrm{~km}$ south to the TESZ in central Poland (Fig. 1). West of this belt is the southtrending East Lithuanian Domain (EL). At the southern extension of the EL lies the Mazowsze Domain. The continental margin setting of the Mazowsze Domain, therefore, resembles the setting of the Svecofennian of southern Finland and Sweden (Claesson et al., 2001).

EUROBRIDGE seismic profile EB'95 from Belarus to Sweden passed north of the Mazowsze Domain, crossing the BPG and EL in Belarus and Lithuania, respectively (EUROBRIDGE Seismic Working Group, 2001; Skridlaite and Motuza, 2001). The crust in the BPG and EL is very thick (ca. $50 \mathrm{~km}$ ) and the boundary between the two domains is not prominent. At the western boundary of the ELD, however, the crust thins to $42-45 \mathrm{~km}$. Both the BPG and the EL have been interpreted as buried granulite terranes (Motuza, 2005) west of the Ukrainian Shield.

Extensive drilling in the BPG, especially near the Polish-Belarus border, has shown that the belt consists mainly of meta-igneous granulites and subordinate high-grade metasediments (Taran and Bogdanova, 2003). There are two main igneous suites, an early (ca. $1.89 \mathrm{Ga}$ ) calc-alkaline suite (Claesson et al., 2001) and a later (ca. $1.80 \mathrm{Ga}$ ), more diverse suite of alkali-calcic and bimodal igneous rocks (Bibikova et al., 1995). The highest $\mathrm{Ar}-\mathrm{Ar}$ ages of metamorphic amphiboles (1.78-1.74 Ga) are considered to record cooling after peak metamorphism at about $1.87 \mathrm{Ga}$ (Bogdanova et al., 2001; Taran and Bogdanova, 2003). The belt has been interpreted as the remains of a subduction complex (Skridlaite and Motuza, 2001). The EL, in contrast, is dominated by amphibolite-facies metagreywackes, meta-volcanics and mafic to ultramafic intrusions (Skridlaite and Motuza, 2001). Nd model ages of the metagreywackes range from 2.41 to $2.29 \mathrm{Ga}$ (Claesson et al., 2001), consistent with the few measured detrital zircon ages that are slightly older, 2.7-2.2 Ga (Marfin et al., 1987; Mansfeld, 2001). The EL belt was metamorphosed over approximately the same period as the BPG, ca. 1.87-1.82 Ga (Bibikova et al., 1996; Taran and Bogdanova, 2003). The EL has been interpreted as a former continental margin arc and back-arc basin (Skridlaite and Motuza, 2001).

\subsection{Basement rocks of central NE Poland}

The present study focused on basement rocks recovered from two boreholes, Monki 2 and Jastrzebna 1, from a region in east central Poland that was defined by Kubicki and Ryka (1982) as the Mazovian or Mazowsze Massif (MD, Fig. 1). This structure was distinguished primarily on the basis of geophysics, being a region of rather homogeneous magnetic and gravimetric character (Fig. 2). Only five holes have been drilled into the basement rocks of the Mazowsze Massif away from the Paleozoic igneous complexes, so little is known about the regional basement lithologies and ages. $\mathrm{K}-\mathrm{Ar}$ biotite ages measured on a pegmatite from the upper part of the Jastrzebna core by Depciuch et al.(1975) range from 2.6 to $1.7 \mathrm{Ga}$, on the basis of which Ryka (1984) proposed that the massif might represent an Archean block. Following isotopic age measurements on mafic granulites in Belarus, however, the presence of Archean crust was called into question (Bogdanova et al., 1994), and Ryka (1998) subsequently proposed that the rocks of the Mazovian Massif are largely of Paleoproterozoic age, a conclusion supported by later measurements of 2.2-2.0 Ga Nd model ages (Claesson and Ryka, 1999). The deposition ages of the metasediments, their metamorphic histories and their provenance remain unknown, however, as does their relationship to structural units distinguished in adjacent regions of Lithuania and Belarus. The crystalline basement of NE Poland is considered to be an integral part of Fennoscandia (Bogdanova, 2005), but the geological links to a specific segment of the EEC have yet to be documented.

\subsection{Jastrzebna}

The crystalline basement intersected by the Jastrzebna 1 borehole (N53 $44^{\prime} 10^{\prime \prime}, \mathrm{E} 23^{\circ} 15^{\prime} 10^{\prime \prime}$ ) is covered by ca. 500 m of Quaternary and Mesozoic sediments. The upper part of the core $(512-570 \mathrm{~m})$ is mainly pegmatite, with some amphibolite. The lower part (570-717 m) consists of intercalated sillimanite-cordierite gneiss (ca. $70 \mathrm{~m}$ ) and biotite gneiss (ca. $60 \mathrm{~m}$; Ryka, 1976). K-Ar biotite ages measured by Depciuch et al. (1975) on one sample of sillimanite-cordierite gneiss (depth $689 \mathrm{~m}$ ) are very dispersed, 2.20-1.41 Ga, which has been interpreted as evidence for a complex metamorphic history (Ryka, 1976).

Contrasts in trace element contents within the Jastrzebna borehole, particularly $\mathrm{Ba}, \mathrm{Sr}, \mathrm{Ni}, \mathrm{Co}, \mathrm{V}, \mathrm{Cr}, \mathrm{Sc}$ and $\mathrm{Ti}$, are indicative of significant geochemical differentiation of the metamorphic rocks (Dziedzic, 1976). The amphibolites are characterised by high levels of $\mathrm{Cr}, \mathrm{Ni}, \mathrm{V}$ and $\mathrm{Co}$, consistent with their having a mafic igneous protolith. The biotite and sillimanite-cordierite gneisses have low levels of $\mathrm{Cr}, \mathrm{Ni}, \mathrm{V}$ and $\mathrm{Co}$, but high $\mathrm{Ba}$ and $\mathrm{Sr}$, consistent with a sedimentary protolith, possibly shales or mudstones (Dziedzic, 1976).

\subsection{Monki}

The Monki 2 borehole (N53 $26^{\prime} 10^{\prime \prime}$, E22 ${ }^{\circ} 44^{\prime} 45^{\prime \prime}$ ) intersected quartzite and quartz schists at a depth of $626 \mathrm{~m}$, succeeded at $745 \mathrm{~m}$ by a seemingly monotonous section of grey gneiss with a few layers of pegmatite and intermediate to mafic meta-volcanic rocks (Wolkowicz, 1996). One sample of meta-volcanic (depth $1488 \mathrm{~m}$ ) has yielded a $\mathrm{Nd}$ model age of ca. $2.06 \mathrm{Ga}$, showing that the igneous protolith was probably of Paleoproterozoic age (Claesson and Ryka, 1999). It has been suggested that the protolith of the Monki grey gneisses was terrigenous sediment (Wolkowicz, 1996), but their stratigraphic relationships have not been closely studied. Metasedimentary sequences of sillimanite gneiss and garnet-biotite-sillimanite gneiss up to $300 \mathrm{~m}$ thick have also been intersected in holes drilled at Czyże, Wigry and Gdansk (Fig. 2), showing the widespread occurrence of these lithologies.

\section{Methodology}

Sixteen samples of paragneiss were selected from the two drill cores for major and trace element analysis. Ten were analysed for whole-rock composition at the ACME Analytical Laboratories, Vancouver, Canada. Trace elements were determined by Inductively Coupled Plasma Mass Spectrometry (ICP-MS). The other six samples, from Jastrzebna, were analysed at the Central Chemical Laboratory of the Polish Geological Institute, Warsaw. Major elements were determined using standard X-ray fluorescence (XRF) fusion techniques. Trace elements were determined by ICP-MS in Canada. Thin sections from all samples were examined on a LEO electron microprobe and imaged by cathodoluminescence (CL) using a VIS-View 900 at the Polish Geological Institute. 
Zircon was separated from two of the samples and monazite from one using small scale, clean, crushing, hydraulic, magnetic and heavy liquid procedures. For zircon analysis, several hundred randomly selected grains from each sample were mounted in epoxy with zircon standards SL13 (238 ppm U) and FC1 $\left({ }^{206} \mathrm{~Pb} /{ }^{238} \mathrm{U}=0.1859\right)$, sectioned by polishing, then documented by transmitted and reflected light microscopy, and CL imaging using an Hitachi S-2250N SEM. After gold coating, selected zircons were analysed for $\mathrm{U}-\mathrm{Th}-\mathrm{Pb}$ isotopes on the SHRIMP II ion microprobe at the Research School of Earth Sciences, ANU, using procedures based on those described by Williams and Claesson (1987). A primary ion beam of ca. $3 \mathrm{nA}, 10 \mathrm{kV} \mathrm{O}_{2}{ }^{-}$was focused to a probe ca. $25 \mu \mathrm{m}$ diameter and the sputtered secondary ions extracted at $10 \mathrm{kV}$, mass analysed at ca. $5000 \mathrm{R}$, and the isotopic species of interest measured on a single ETP electron multiplier by cyclic peak stepping. Fourteen grains of high-clarity monazite from one sample were mounted with monazite standard Thompson Mine WB.T.329 (radiogenic ${ }^{206} \mathrm{~Pb} /{ }^{238} \mathrm{U}=0.3152, \mathrm{U}=\mathrm{ca} .2100 \mathrm{ppm}$ ) and six analysed by a similar procedure, except that weak filtering out of low energy ions (ca. 50\% secondary beam loss) was used to eliminate a molecular isobar at mass 204. Isotopic compositions were measured directly, without correction for mass fractionation (ca. $2 \%$ /AMU). Common Pb levels were, in some cases, a little higher than expected from laboratory contamination so were corrected, using ${ }^{204} \mathrm{~Pb}$, assuming a model $\mathrm{Pb}$ isotopic composition consistent with the approximate age of each grain (Cumming and Richards, 1975). Corrections for $\mathrm{Pb}-\mathrm{U}$ fractionation utilised a power-law relationship between $\mathrm{UO}^{+} / \mathrm{U}^{+}$and $\mathrm{Pb}^{+} / \mathrm{U}^{+}$(Claoué-Long et al., 1995). Ages were calculated using the constants recommended by the IUGS Subcommission on Geochronology (Steiger and Jäger, 1977). Analytical uncertainties listed in Table S1 and plotted in Fig. 7 are one standard error precision estimates. Uncertainties in the ages cited in the text are 95\% confidence limits (95\% c.l.), namely $t \sigma$, where $t$ is 'Student's $t$ ' (Student, 1908).

\section{Sample selection}

\subsection{Jastrzebna}

Ten samples from the Jastrzebna core, from the depth interval 553-711 m, were selected for petrological examination and chemical analysis. Most of them were cordierite-sillimanite gneisses. Two (J-522 and J-553) were biotite gneisses associated with hornblenderich horizons that have been interpreted as intercalations of mafic volcanogenic material (Dziedzic, 1976). Sample J-598 was collected from the main homogenous, but partially migmatised, sequence of cordierite-sillimanite gneiss (589.0-598.7 m). Typically, the mineral assemblage in these gneisses is plagioclase $\left(\mathrm{An}_{30-42}\right), \mathrm{K}-$ feldspar, quartz, biotite, cordierite and sillimanite, with a high abundance of ilmenite-magnetite, which is responsible for the local magnetic anomaly. The plagioclase to K-feldspar ratio is about 3:1. Accessory minerals include zircon and monazite.

The newly-calibrated biotite thermometer of Henry and others (2005), applied to sample J-598, gives metamorphic temperatures of $540-625^{\circ} \mathrm{C}$ (Wiszniewska et al., 2006), reflecting amphibolite facies metamorphism of this part of the gneiss sequence.

\subsection{Monki}

Six samples of 'grey gneiss' from the Monki 2 core, distributed over the depth range from 819 to $1520 \mathrm{~m}$, were selected for close examination. Rare thin layers of intermediate to mafic volcanogenic amphibolite were avoided. The Monki grey gneisses have a very simple mineralogy. The main mineral constituents, in order of decreasing abundance, are quartz, K-feldspar, plagioclase, biotite, muscovite and epidote, with accessory apatite, zircon, opaque oxides and chlorite. Typically, the epidote cores are more Fe-rich than the rims, but the reverse also occurs. Laminae of biotite, muscovite and epidote intermingle with laminae dominated by quartz and feldspars on a thin-section scale. The plagioclase is mostly oligoclase $\left(\mathrm{An}_{15-25}\right)$, but albite is also present.

Sample M-819, for geochronology, was collected from the upper part of the Monki gneiss sequence (depth $819 \mathrm{~m}$ ). It is more quartz rich, and has less biotite relative to muscovite, than the grey gneisses lower in the sequence. The rare plagioclase has mostly been replaced by fine-grained muscovite (sericite).

Metamorphic temperatures at Monki, estimated using biotite geothermometry (Henry et al., 2005) range from $475-520^{\circ} \mathrm{C}$ at $819 \mathrm{~m}$ depth (greenschist facies) to $595-620^{\circ} \mathrm{C}$ at deeper levels, 1240-1460 m (amphibolite facies).

\section{Geochemistry}

Chemical compositions of the analysed Jastrzebna and Monki rocks are listed in Table 1 . Elements not analysed are marked by an asterisk $\left({ }^{*}\right)$. Selected element abundances and element ratios are compiled in Table 2. The Jastrzebna and Monki gneisses are mostly of intermediate composition. $\mathrm{SiO}_{2}$ and $\mathrm{Al}_{2} \mathrm{O}_{3}$ concentrations are 58-68 and 13-18 wt.\%, respectively. The ratios $\mathrm{Si} / \mathrm{Al}$ and $\mathrm{K} / \mathrm{Na}$ are moderate $\left(\mathrm{SiO}_{2} / \mathrm{Al}_{2} \mathrm{O}_{3}=3.0-5.4\right.$ at Jastrzebna, 3.3-4.0 at Monki; $\mathrm{K}_{2} \mathrm{O} / \mathrm{Na}_{2} \mathrm{O}$ ranges from 0.23 to 1.39 and 1.46 to 2.01 at Jastrzebna and Monki, respectively).

Type Svecofennian metasediments exposed in southern Finland have similar compositions (Kähkönen and Leveinen, 1994; Lahtinen, 1996). In addition, low silica rocks reported from the Tampere-Hämeenlinna area resemble the more mafic compositions within the Jastrzebna core (e.g. J-601, J-596, J-590; 51-57\% $\mathrm{SiO}_{2}$ ).

The Jastrzebna protolith sediments were relatively immature. This is reflected in lower $\mathrm{SiO}_{2}$ contents than the typical exposed Svecofennian and higher $\mathrm{Fe}$ and $\mathrm{Ti}$ (typically 6-13 wt.\% $\mathrm{Fe}_{2} \mathrm{O}_{3}$, 0.7-1.0 wt.\% $\mathrm{TiO}_{2}$ ). The Fe and Ti contents of the Monki metasediments are not quite so high (6-11 and $0.5-0.9 \mathrm{wt} . \%$, respectively). These compositions are reflected in the high concentrations of titaniferous iron oxides observed in thin section. On the sediment classification diagram of Herron (1988), the compositions of the Jastrzebna sediments straddle the boundary between the shale and Fe-shale fields (Fig. 3a). The Monki metasediment compositions, with lower Fe, lie mostly within the shale field.

The Chemical Index of Alteration (CIA) provides a further measure of the maturity of the sedimentary protolith (Nesbit and Young, 1982). Intense chemical weathering results in the depletion of the alkali and alkali earth elements, which produces CIA values $\left(\left[\mathrm{Al}_{2} \mathrm{O}_{3} /\left(\mathrm{Al}_{2} \mathrm{O}_{3}+\mathrm{CaO}+\mathrm{Na}_{2} \mathrm{O}+\mathrm{K}_{2} \mathrm{O}\right)\right] \times 100\right)$ close to 100 . The metasediments from Jastrzebna and Monki have values as low as 57-69, indicating a very low degree of chemical weathering (Table 1). Similarly low CIA values are found in the Svecofennian metasediments of Finland, typically 53-67 (Lahtinen et al., 2002).

All samples examined for this study were enriched in light rare earth elements (LREE), with La to Pr contents averaging more than 100 times chondrites, similar to the levels observed in the Svecofennian metasediments of Finland (Lahtinen et al., 2002; Fig. 4). The total REE contents of the Monki samples are more uniform than those from Jastrzebna. In contrast, the HREE characteristics of the Polish metasediments, as reflected in their $(\mathrm{Gd} / \mathrm{Yb})_{\mathrm{N}}$ ratios (Table 2; Fig. 4), differ significantly between the two sites. The Monki samples have $(\mathrm{Gd} / \mathrm{Yb})_{\mathrm{N}}$ ratios in the range $0.9-1.7$, very similar to the Svecofennian metasediments. $(\mathrm{Gd} / \mathrm{Yb})_{\mathrm{N}}$ ratios in the Jastrzebna metasediments, however, range from 3.1 to 4.9 , indicative of a relative depletion in HREE. In this respect, the Monki metasediments resemble average Post-Archean Australian Shale (PAAS, Taylor and McLennan, 1985), and the Jastrzebna sediments resemble the com- 
Table 1

Geochemical composition of paragneisses from the Monki and Jastrzebna boreholes.

\begin{tabular}{|c|c|c|c|c|c|c|c|c|c|c|c|c|c|c|}
\hline & \multicolumn{6}{|l|}{ Monki } & \multicolumn{8}{|l|}{ Jastrzebna } \\
\hline & $\begin{array}{l}\text { M-819 } \\
\text { gn bt-m }\end{array}$ & $\begin{array}{l}\text { M-1347 } \\
\text { gn bt-m }\end{array}$ & $\begin{array}{l}\text { M-1460 } \\
\text { gn-bt }\end{array}$ & $\begin{array}{l}\text { M-1468a } \\
\text { gn-bt }\end{array}$ & $\begin{array}{l}\text { M-1468b } \\
\text { gn-bt }\end{array}$ & $\begin{array}{l}\text { M-1520 } \\
\text { gn-bt }\end{array}$ & $\begin{array}{l}\text { J-595 } \\
\text { gn-crd-sil }\end{array}$ & $\begin{array}{l}\text { J-601 } \\
\text { gn-crd-sil }\end{array}$ & $\begin{array}{l}\text { J-595.5 } \\
\text { gn-crd-sil }\end{array}$ & $\begin{array}{l}\text { J-598 } \\
\text { gn-crd-sil }\end{array}$ & $\begin{array}{l}J-590 \\
\text { gn-bt }\end{array}$ & $\begin{array}{l}J-626 \\
\text { gn-bt }\end{array}$ & $\begin{array}{l}\text { J-602 } \\
\text { gn-bt }\end{array}$ & $\begin{array}{l}J-553 \\
\text { gn-bt }\end{array}$ \\
\hline $\mathrm{SiO}_{2}$ (wt.\%) & 61.0 & 65.0 & 64.8 & 63.4 & 57.8 & 58.6 & 62.3 & 50.9 & 54.3 & 62.5 & 57.0 & 67.7 & 65.1 & 68.7 \\
\hline $\mathrm{Al}_{2} \mathrm{O}_{3}$ (wt.\%) & 18.5 & 16.1 & 15.4 & 16.7 & 17.3 & 17.6 & 16.6 & 14.8 & 18.4 & 17.0 & 17.7 & 13.8 & 14.7 & 12.7 \\
\hline $\mathrm{Fe}_{2} \mathrm{O}_{3}(\mathrm{wt} . \%)$ & 5.9 & 6.9 & 7.5 & 7.6 & 10.4 & 10.6 & 8.8 & 22.9 & 13.5 & 10.0 & 10.9 & 7.3 & 8.0 & 6.3 \\
\hline MgO (wt.\%) & 2.1 & 2.2 & 2.1 & 2.1 & 3.1 & 2.5 & 2.8 & 1.6 & 4.1 & 1.4 & 3.5 & 2.4 & 2.7 & 2.1 \\
\hline $\mathrm{CaO}$ (wt.\%) & 2.1 & 1.5 & 1.6 & 1.4 & 1.6 & 1.3 & 2.8 & 3.3 & 2.4 & 3.7 & 2.6 & 3.0 & 3.1 & 2.2 \\
\hline $\mathrm{Na}_{2} \mathrm{O}$ (wt.\%) & 3.1 & 1.9 & 1.9 & 1.8 & 1.9 & 1.7 & 2.6 & 2.8 & 2.3 & 3.5 & 2.7 & 2.7 & 2.8 & 2.3 \\
\hline $\mathrm{K}_{2} \mathrm{O}$ (wt.\%) & 4.5 & 3.1 & 3.1 & 3.4 & 3.5 & 3.6 & 1.9 & 1.3 & 2.6 & 0.8 & 2.2 & 2.1 & 2.2 & 3.1 \\
\hline $\mathrm{TiO}_{2}$ (wt.\%) & 0.5 & 0.6 & 0.7 & 0.6 & 0.9 & 1.0 & 0.8 & 1.0 & 1.1 & 0.5 & 1.0 & 0.7 & 0.8 & 0.7 \\
\hline $\mathrm{P}_{2} \mathrm{O}_{5}$ (wt.\%) & 0.06 & 0.09 & 0.13 & 0.14 & 0.13 & 0.11 & 0.04 & 0.03 & 0.03 & 0.03 & 0.04 & 0.04 & 0.03 & 0.03 \\
\hline $\mathrm{MnO}$ (wt.\%) & 0.06 & 0.07 & 0.06 & 0.06 & 0.09 & 0.10 & 0.08 & 0.11 & 0.11 & 0.06 & 0.10 & 0.07 & 0.07 & 0.05 \\
\hline $\mathrm{Cr}_{2} \mathrm{O}_{3}$ (wt.\%) & 0.01 & 0.02 & 0.02 & 0.01 & 0.02 & 0.02 & 0.01 & 0.02 & 0.03 & 0.01 & 0.02 & 0.01 & 0.01 & 0.02 \\
\hline LOI (wt.\%) & 2.0 & 2.1 & 2.6 & 2.5 & 3.0 & 2.6 & 1.1 & 0.8 & 1.0 & 0.6 & $*$ & $*$ & $*$ & $*$ \\
\hline Total (wt.\%) & 99.7 & 99.6 & 99.8 & 99.8 & 99.8 & 99.8 & 99.9 & 99.6 & 99.9 & 100.1 & 97.8 & 99.7 & 99.5 & 98.1 \\
\hline $\mathrm{CIA}$ & 61.0 & 66.9 & 66.2 & 68.0 & 66.9 & 69.4 & 62.3 & 62.0 & 67.7 & 63.0 & 65.7 & 59.5 & 59.9 & 58.3 \\
\hline $\mathrm{Rb}(\mathrm{ppm})$ & 242 & 111 & 128 & 124 & 149 & 119 & 91 & 60 & 122 & 33 & 101 & 95 & 116 & 122 \\
\hline $\mathrm{Ba}(\mathrm{ppm})$ & 835 & 606 & 635 & 767 & 711 & 800 & 737 & 269 & 737 & 274 & 815 & 545 & 637 & 1033 \\
\hline $\mathrm{Nb}(\mathrm{ppm})$ & 14 & 10 & 12 & 11 & 13 & 14 & 12 & 11 & 14 & 3 & 10 & 14 & 19 & 18 \\
\hline $\mathrm{Ni}(\mathrm{ppm})$ & 40 & 70 & 116 & 63 & 98 & 106 & 72 & 103 & 198 & 35 & 103 & 58 & 71 & 50 \\
\hline $\mathrm{Sr}(\mathrm{ppm})$ & 280 & 186 & 174 & 154 & 173 & 157 & 336 & 349 & 290 & 434 & 314 & 256 & 323 & 288 \\
\hline $\mathrm{V}(\mathrm{ppm})$ & 95 & 96 & 116 & 113 & 139 & 122 & 121 & 282 & 196 & 158 & 175 & 129 & 137 & 113 \\
\hline $\mathrm{Y}(\mathrm{ppm})$ & 35 & 15 & 31 & 22 & 34 & 26 & 8 & 17 & 9 & 7 & 9 & 10 & 7 & 6 \\
\hline $\mathrm{Pb}(\mathrm{ppm})$ & 17 & 5 & 6 & 5 & 7 & 4 & 4 & * & $*$ & 2 & 18 & 16 & 16 & 22 \\
\hline $\mathrm{Ta}(\mathrm{ppm})$ & 1 & 1 & 1 & 1 & 1 & 2 & 1 & 1 & 1 & 0 & * & * & * & * \\
\hline $\mathrm{Hf}$ (ppm) & 4 & 5 & 6 & 4 & 6 & 5 & 7 & 32 & 7 & 4 & $*$ & $*$ & $*$ & * \\
\hline $\mathrm{Zr}(\mathrm{ppm})$ & 156 & 174 & 194 & 120 & 179 & 160 & 212 & 1014 & 257 & 121 & 207 & 159 & 207 & 392 \\
\hline Th (ppm) & 13 & 20 & 15 & 11 & 16 & 17 & 9 & 31 & 22 & 9 & 17 & 15 & 9 & 8 \\
\hline $\mathrm{U}(\mathrm{ppm})$ & 4 & 4 & 3 & 3 & 5 & 3 & 1 & 2 & 1 & 1 & $<3$ & $<3$ & $<3$ & $<3$ \\
\hline Co (ppm) & 14 & 24 & 24 & 23 & 34 & 25 & 36 & 42 & 44 & 21 & 41 & 26 & 31 & 20 \\
\hline $\mathrm{Sc}(\mathrm{ppm})$ & 15 & 16 & 18 & 14 & 21 & 16 & 21 & 17 & 25 & 8 & 15 & 17 & 11 & 6 \\
\hline Cs (ppm) & 14 & 6 & 6 & 5 & 9 & 6 & 2 & 1 & 3 & 1 & * & * & * & * \\
\hline $\mathrm{La}(\mathrm{ppm})$ & 34 & 46 & 47 & 40 & 54 & 54 & 61 & 88 & 35 & 36 & 43 & 44 & 30 & 29 \\
\hline $\mathrm{Ce}(\mathrm{ppm})$ & 67 & 104 & 92 & 79 & 106 & 104 & 116 & 166 & 62 & 67 & 74 & 74 & 44 & 50 \\
\hline $\operatorname{Pr}(\mathrm{ppm})$ & 7 & 11 & 10 & 8 & 12 & 11 & 12 & 17 & 6 & 7 & * & * & * & * \\
\hline $\mathrm{Nd}(\mathrm{ppm})$ & 26 & 42 & 38 & 32 & 44 & 42 & 44 & 62 & 25 & 23 & * & * & $*$ & * \\
\hline $\mathrm{Sm}(\mathrm{ppm})$ & 5.2 & 7.1 & 6.7 & 5.4 & 7.7 & 7.2 & 6.5 & 9.1 & 3.8 & 3.6 & $*$ & * & * & $*$ \\
\hline $\mathrm{Eu}(\mathrm{ppm})$ & 1.1 & 1.3 & 1.2 & 1.1 & 3.2 & 1.3 & 1.5 & 1.6 & 1.3 & 1.8 & $*$ & $*$ & $*$ & * \\
\hline Gd (ppm) & 4.2 & 4.8 & 5.2 & 4.4 & 5.7 & 5.4 & 4.1 & 5.1 & 2.4 & 2.4 & $*$ & $*$ & * & * \\
\hline $\mathrm{Tb}(\mathrm{ppm})$ & 0.8 & 0.7 & 0.9 & 0.7 & 2.1 & 0.9 & 0.5 & 0.7 & 0.3 & 0.3 & $*$ & * & $*$ & $*$ \\
\hline Dy (ppm) & 5.0 & 3.1 & 5.1 & 3.8 & 5.3 & 4.7 & 2.1 & 3.0 & 1.5 & 1.4 & $*$ & $*$ & $*$ & * \\
\hline Ho (ppm) & 1.1 & 0.5 & 1.0 & 0.7 & 1.1 & 0.9 & 0.3 & 0.5 & 0.2 & 0.2 & $*$ & $*$ & * & * \\
\hline $\operatorname{Er}(\mathrm{ppm})$ & 3.5 & 1.1 & 2.9 & 2.1 & 3.2 & 2.3 & 0.6 & 1.5 & 0.6 & 0.5 & * & $*$ & * & $*$ \\
\hline $\operatorname{Tm}(\mathrm{ppm})$ & 0.5 & 0.2 & 0.5 & 0.3 & 0.5 & 0.4 & 0.1 & 0.2 & 0.1 & 0.1 & $*$ & $*$ & $*$ & $*$ \\
\hline $\mathrm{Yb}(\mathrm{ppm})$ & 3.8 & 1.1 & 2.9 & 2.1 & 7.4 & 2.6 & 0.7 & 2.0 & 0.6 & 0.5 & * & $*$ & $*$ & * \\
\hline $\mathrm{Lu}(\mathrm{ppm})$ & 0.6 & 0.2 & 0.4 & 0.3 & 0.5 & 0.4 & 0.1 & 0.4 & 0.1 & 0.1 & * & $*$ & $*$ & * \\
\hline
\end{tabular}

position of TTG igneous rocks (Martin and Moyen, 2005; Martin et al., 2005). The metasediments from the two sites also differ in the size of their Eu anomalies. With the exception of one mafic subsample (1468b), the Monki metasediments have pronounced negative Eu anomalies $\left(\mathrm{Eu} / \mathrm{Eu}^{*}=0.6-0.7\right)$. The anomalies in the Jastrzebna samples are smaller or even positive $\left(\mathrm{Eu} / \mathrm{Eu}^{*}=0.7-1.8\right)$. This reflects the higher plagioclase contents of the Jastrzebna samples which, in combination with the differences in HREE, in turn reflects the greater immaturity of the Jastrzebna sedimentary protolith.

The Polish metasediments show different degrees of uniformity in some of the trace elements that concentrate in accessory minerals (e.g. Sc, U, Th), but the average values resemble those of the Finnish Svecofennian. There are also marked contrasts, however. The Polish samples have higher average levels of elements such as $\mathrm{V}$, Co and $\mathrm{Ni}$, which probably reflects a higher abundance of mafic rocks in their source region.

\subsection{Implications for tectonic setting}

Roser and Korsh (1986) proposed that the tectonic setting of sediments can be deduced from their $\mathrm{SiO}_{2}$ and alkali element ratios. On their criteria, the major element compositions of the Jastrzebna and Monki paragneisses indicate deposition in arc and active margin settings, respectively. Trace elements provide a much more satisfactory basis for discrimination, however. Sediments from arcs and continental margins, for example, have very different La-Sc-Th compositions from sediments deposited in ocean island environments (Bhatia and Crook, 1986). In this respect, the Polish sediments have a clear continental affinity (Fig. 3c). The same affinity is evident when Th-Sc-Zr contents are compared (Fig. 3d).

An even better discrimination can be made if the trace elements are considered in terms of their relative compatibility in igneous melts. Normalised to the average trace element content of the upper continental crust (Taylor and McLennan, 1985), the trace element compositions of these Mazowsze metasediments show marked relative depletions in $\mathrm{Nb}-\mathrm{Ta}$ and enrichments in $\mathrm{Ni}$ and V. Depletion in both $\mathrm{Nb}$ and $\mathrm{Ta}$ is a feature of greywacke sediments derived from continental sources (Fig. 5). The enrichments in $\mathrm{Ni}$ and $\mathrm{V}$ are not a tectonic discriminant, but are possibly related to the local high abundance of Fe-Ti oxides. The Mazowsze metasediments differ from one another in their Y contents, Jastrzebna showing Y depletion and Monki not. Low Y contents $(<15 \mathrm{ppm})$ are a feature of 
Table 2

Main elemental ratios for Monki and Jastrzebna paragneisses, compared to Svecofennian metasediment compositions from Lahtinen et al. (2002).

\begin{tabular}{|c|c|c|c|c|c|c|c|c|c|c|c|c|c|c|c|c|c|c|c|}
\hline & \multicolumn{6}{|c|}{${ }^{\mathrm{a}}$ Monki } & \multicolumn{4}{|c|}{${ }^{\text {a Jastrzebna }}$} & \multicolumn{6}{|c|}{${ }^{\mathrm{b}}$ Svecofennian metasediments, southern Finland } & & & \\
\hline & $\begin{array}{c}\text { M-819 } \\
\text { gn bt-m. }\end{array}$ & $\begin{array}{l}\mathrm{M}-1347 \\
\text { gn bt-m. }\end{array}$ & $\begin{array}{c}\text { M-1460 } \\
\text { gn-bt }\end{array}$ & $\begin{array}{c}M-1468 a \\
\text { gn-bt }\end{array}$ & $\begin{array}{c}M-1468 b \\
\text { gn-bt }\end{array}$ & $\begin{array}{c}\mathrm{M}-1520 \\
\mathrm{gn}-\mathrm{bt}\end{array}$ & $\begin{array}{c}\mathrm{J}-595 \\
\text { gn-crd-sil }\end{array}$ & $\begin{array}{c}\mathrm{J}-601 \\
\text { gn-crd-sil }\end{array}$ & $\begin{array}{c}\text { J-595.5 } \\
\text { gn-crd-sil }\end{array}$ & $\begin{array}{c}\mathrm{J}-598 \\
\text { gn-crd-sil }\end{array}$ & $\begin{array}{l}\text { CSPIA } \\
\text { A1199 } \\
\end{array}$ & $\begin{array}{c}\text { CSL2 } \\
\text { L1556/5 }\end{array}$ & $\begin{array}{c}\text { CSL1 } \\
\text { N95/82 }\end{array}$ & $\begin{array}{c}\mathrm{SSI} \\
\mathrm{L} 15 / 1\end{array}$ & $\begin{array}{c}\mathrm{SSI} \\
\mathrm{L} 15 / 4\end{array}$ & $\begin{array}{c}\text { SSM } \\
\text { A1557/2 } \\
\end{array}$ & & & \\
\hline $\mathrm{SiO}_{2} / \mathrm{Al}_{2} \mathrm{O}_{3}$ & 3.3 & 4.0 & 4.2 & 3.8 & 3.3 & 3.3 & 3.7 & 3.4 & 3.0 & 3.7 & 5.1 & 3.7 & 5.1 & 4.6 & 3.3 & 3.6 & & & \\
\hline $\mathrm{K}_{2} \mathrm{O} / \mathrm{Na}_{2} \mathrm{O}$ & 1.5 & 1.6 & 1.6 & 1.9 & 1.8 & 2.0 & 0.8 & 0.5 & 1.1 & 0.2 & 1.1 & 1.5 & 1.1 & 0.4 & 3.0 & 5.5 & & & \\
\hline sum REE & 160 & 223 & 214 & 180 & 251 & 237 & 248 & 357 & 139 & 143 & 251 & 159 & 199 & 188 & 199 & 175 & & & \\
\hline $\mathrm{La} / \mathrm{Yb}$ & 9.10 & 42.09 & 16.39 & 19.28 & 7.35 & 20.38 & 87.68 & 43.18 & 55.71 & 72.65 & 31.06 & 13.95 & 21.69 & 14.09 & 16.50 & 16.98 & & & \\
\hline $\mathrm{La} / \mathrm{Yb})_{\mathrm{N}}$ & 6.54 & 30.19 & 11.76 & 13.83 & 5.27 & 14.62 & 62.89 & 30.98 & 39.96 & 52.11 & 22.28 & 10.01 & 15.56 & 10.11 & 11.83 & 12.18 & & ce elem & \\
\hline $\mathrm{La} / \mathrm{Sm})_{\mathrm{N}}$ & 4.30 & 4.21 & 4.55 & 4.82 & 4.54 & 4.82 & 6.01 & 6.24 & 5.96 & 6.38 & 4.58 & 3.91 & 4.81 & 4.08 & 4.19 & 4.65 & char & acteristic & of \\
\hline $\mathrm{Gd} / \mathrm{Yb})_{\mathrm{N}}$ & 0.91 & 3.63 & 1.49 & 1.73 & 0.64 & 1.68 & 4.92 & 2.07 & 3.16 & 4.07 & 3.34 & 1.73 & 2.23 & 1.84 & 1.93 & 1.93 & grey & wackes & rom \\
\hline Eu/Eu* & 0.70 & 0.66 & 0.61 & 0.69 & 1.42 & 0.60 & 0.82 & 0.65 & 1.19 & 1.80 & 0.46 & 0.75 & 0.54 & 0.88 & 0.61 & 0.60 & various & tectonic & settings \\
\hline & & & & & & & & & & & & & & & & & CIA & $\mathrm{ACM}$ & PM \\
\hline Th/Sc & 0.89 & 1.23 & 0.81 & 0.77 & 0.78 & 1.08 & 0.42 & 1.83 & 0.89 & 1.11 & 1.05 & 0.49 & 1.16 & 0.76 & 0.58 & 0.57 & 0.85 & 2.59 & 3.06 \\
\hline $\mathrm{La} / \mathrm{Sc}$ & 2.29 & 2.89 & 2.62 & 2.87 & 2.58 & 3.36 & 2.88 & 5.18 & 1.40 & 4.45 & 3.45 & 1.83 & 3.36 & 2.90 & 2.18 & 1.89 & 1.82 & 4.55 & 6.25 \\
\hline $\mathrm{La} / \mathrm{Th}$ & 2.56 & 2.35 & 3.23 & 3.73 & 3.32 & 3.11 & 6.88 & 2.82 & 1.58 & 4.00 & 3.27 & 3.72 & 2.90 & 3.80 & 3.74 & 3.32 & 2.36 & 1.77 & 2.20 \\
\hline $\mathrm{Sc} / \mathrm{Cr}$ & 0.24 & 0.13 & 0.13 & 0.19 & 0.18 & 0.14 & 0.31 & 0.11 & 0.11 & 0.19 & 0.11 & 0.26 & 0.16 & 0.11 & 0.16 & 0.15 & 0.32 & 0.30 & 0.16 \\
\hline $\mathrm{La} / \mathrm{Y}$ & 0.98 & 3.12 & 1.51 & 1.81 & 1.59 & 2.06 & 7.96 & 5.31 & 3.77 & 5.48 & 2.42 & 1.26 & 1.86 & 1.30 & 1.50 & 1.44 & 1.02 & 1.33 & 1.31 \\
\hline $\mathrm{Zr} / \mathrm{Th}$ & 11.61 & 8.84 & 13.25 & 11.08 & 11.01 & 9.23 & 24.03 & 32.50 & 11.57 & 13.56 & 25.47 & 15.87 & 14.70 & 19.60 & 13.80 & 15.26 & 21.50 & 9.50 & 19.10 \\
\hline
\end{tabular}

${ }^{a}$ This work

${ }^{\mathrm{b}}$ From Lahtinen et al. (2002)

${ }^{c}$ From Bhatia and Crook (1986) 
(a)

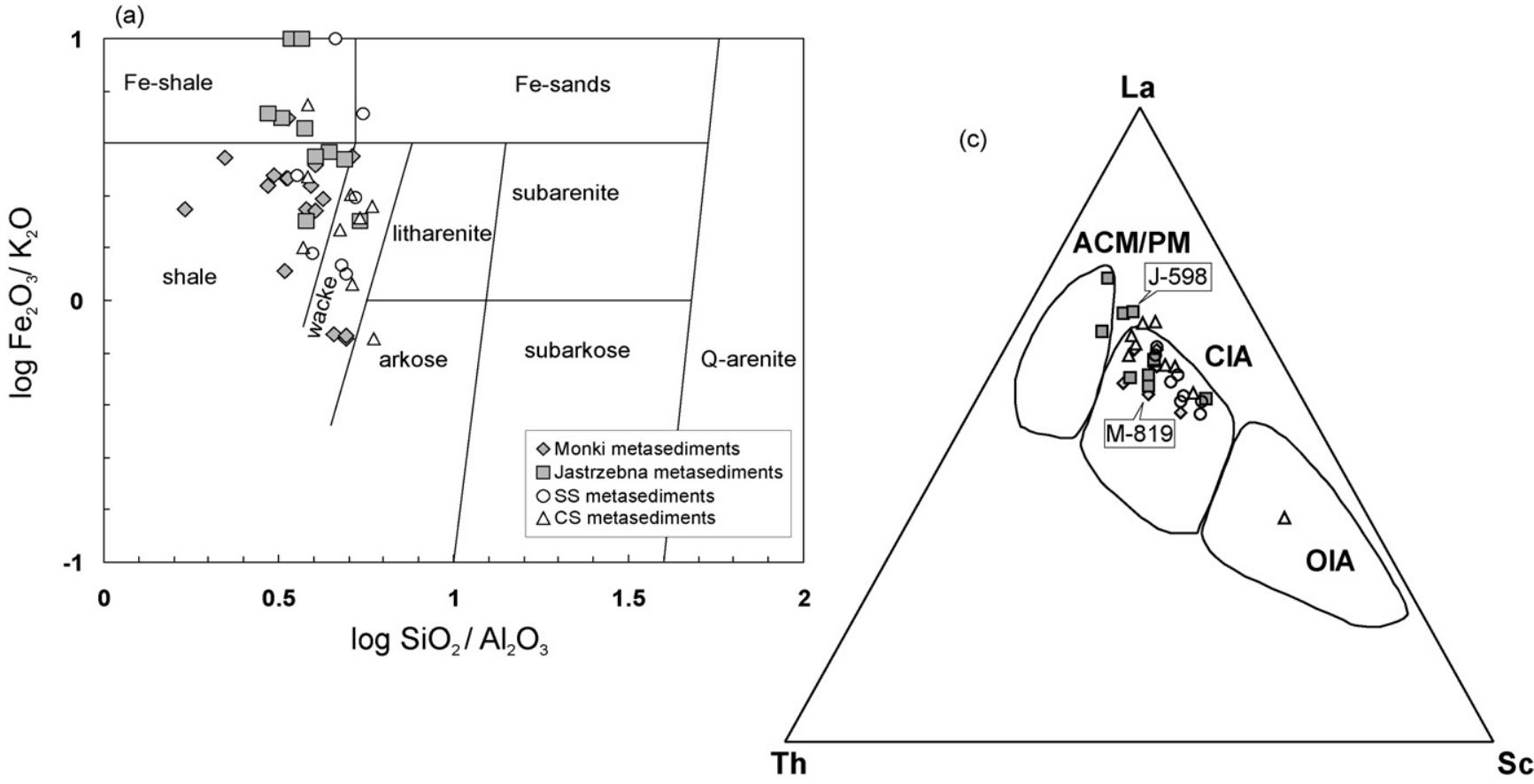

(b)

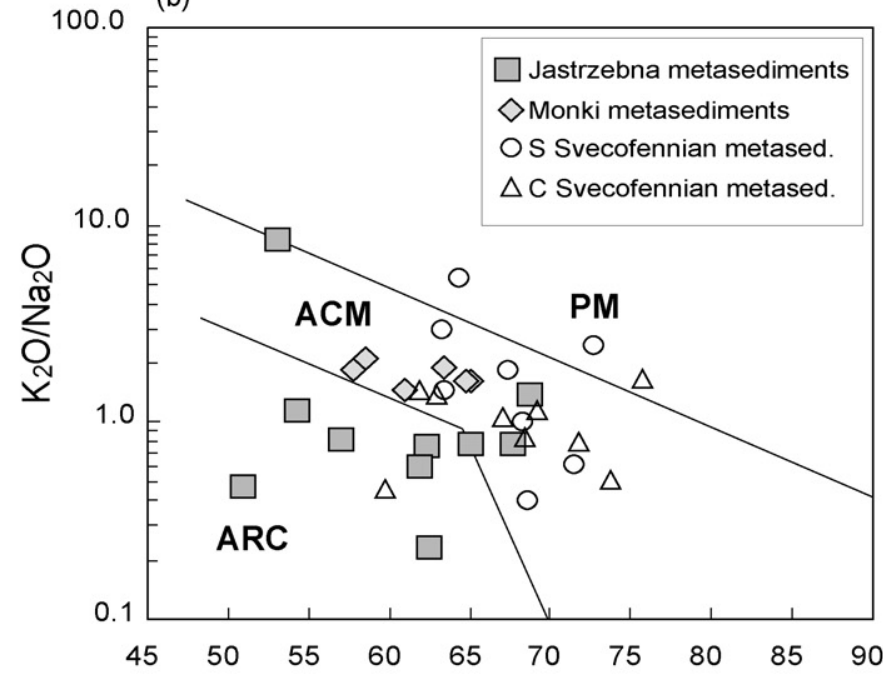

$\mathrm{SiO}_{2}[\mathrm{wt} . \%]$

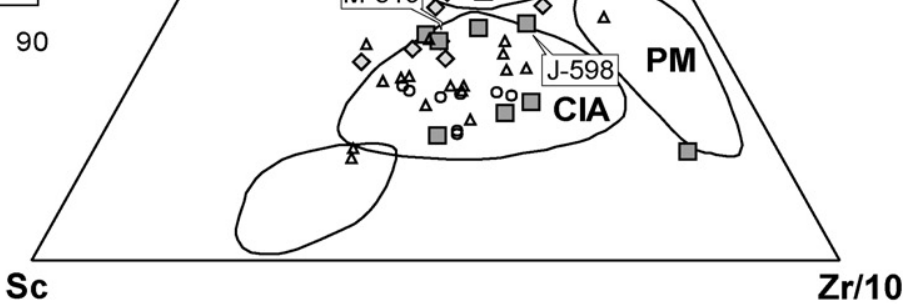

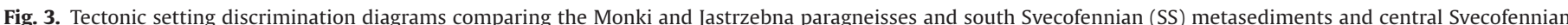

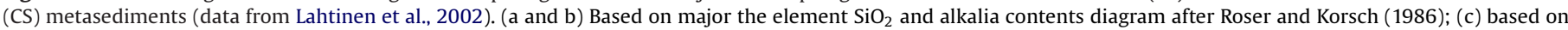

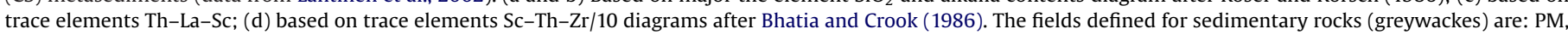
passive margin; ACM, active continental margin; CIA, continental island arc; OIA, oceanic island-arc. The positions of key samples are marked.

TTG igneous rocks (Martin et al., 2005), so the depletion in the Jastrzebna metasediments possibly reflects a higher abundance of such rocks in their source region. This conclusion is supported by the observation that both the Jastrzebna metasediments and TTG have similar levels of depletion in the HREE.

These distinctive trace element ratios and the same relative depletions are also found in the Svecofennian metasediments from Finland (Fig. 4c).

\section{U-Pb geochronology}

\subsection{Paragneiss Monki 819}

The sample selected from the Monki drill core for zircon dating was grey paragneiss from a depth of $819 \mathrm{~m}$. The zircon grains were mostly large (100-200 $\mu \mathrm{m}$ diameter), pale to dark brown, finely fractured, clear to turbid, subhedral prismatic crystals with 

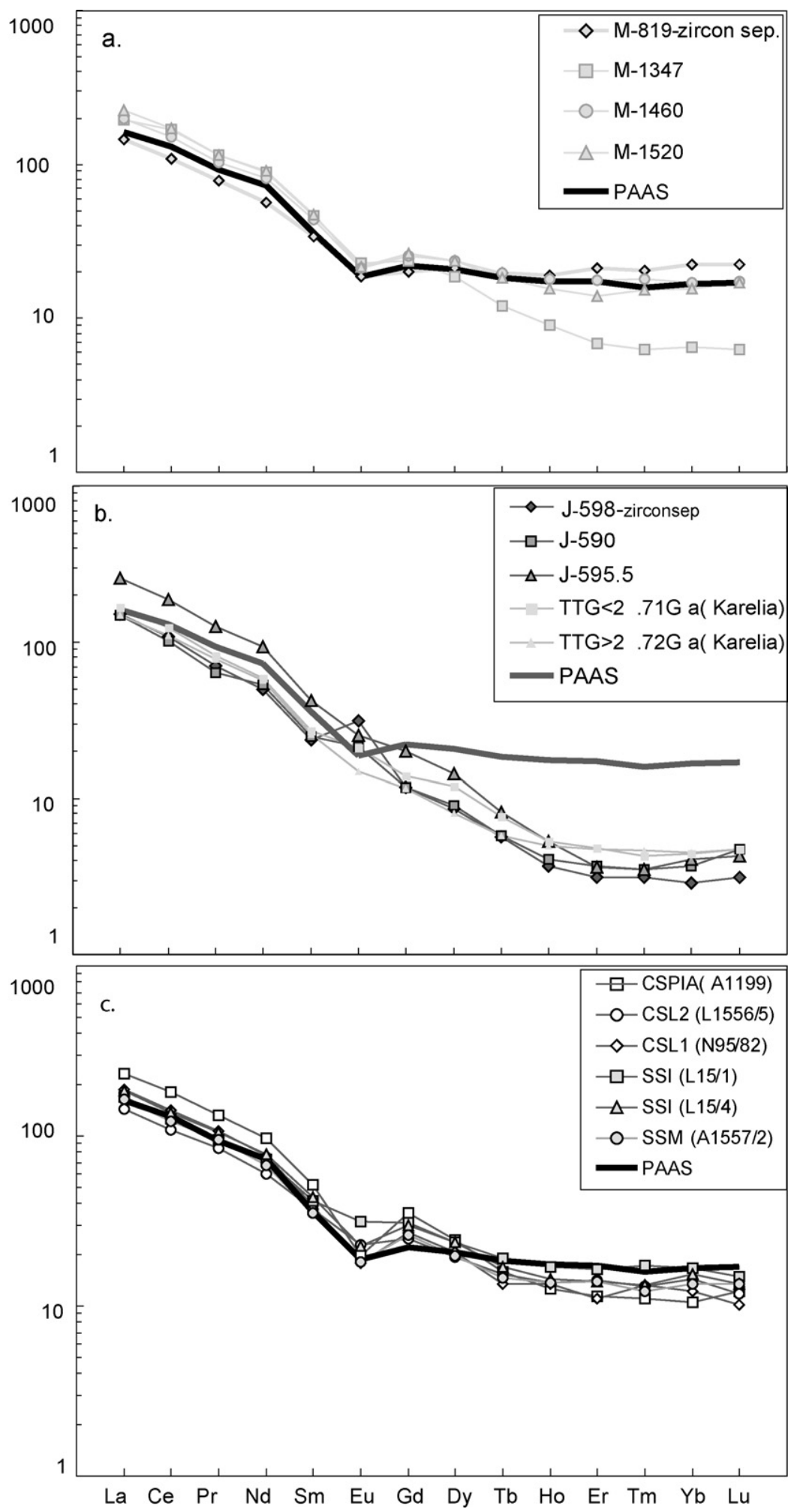

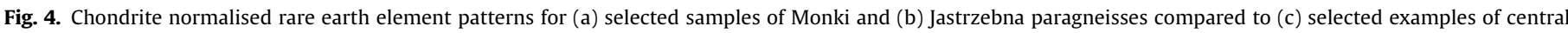

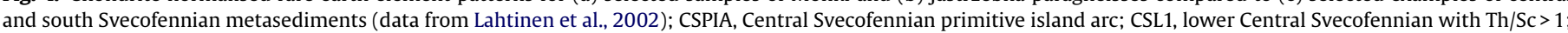

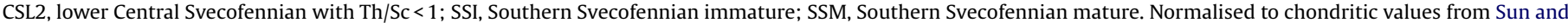
McDonough (1989). The standard composition of average Post-Archean Australian Shale (PAAS) after McLennan (1989) is shown for comparison.

moderate to high aspect ratios (2-6). Many grains had relatively well preserved crystal faces and clearly visible oscillatory zoning. In transmitted light the zoning showed up as differences in turbidity and refractive index; in reflected light it was evident as very pronounced differences in reflectance. The true complex- ity of the grains was revealed by CL imaging (Fig. 6). Every grain consisted of a large zircon core surrounded by a very weakly luminescent overgrowth. The cores ranged from euhedral zircon grains to angular fragments of crystals to strongly rounded grains. The zoning in the cores ranged from simple oscillatory zoning to sector 

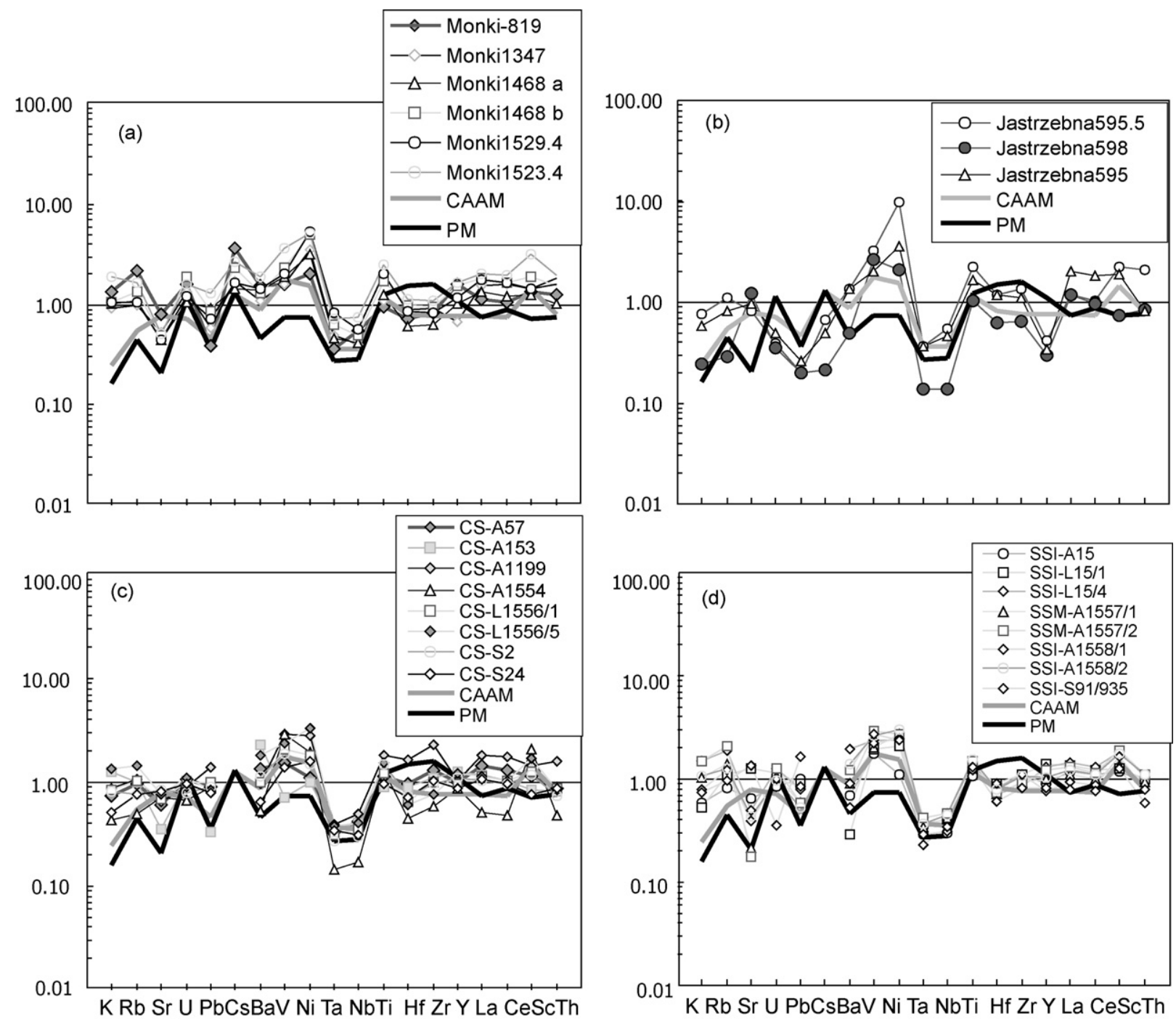

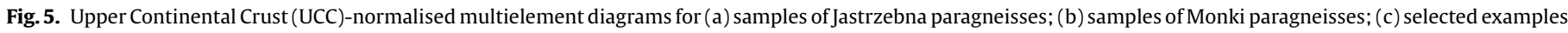

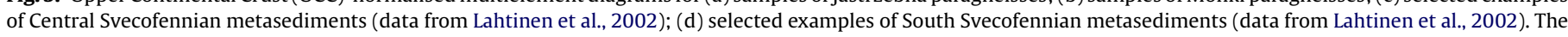

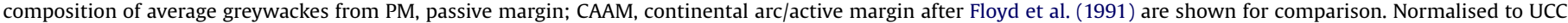
values from Taylor and McLennan (1985).

zoning to banded zoning. Some cores showed evidence of extensive recrystallisation-in others there was no visible zoning at all.

The cores and overgrowths had very different $U$ and Th contents (Table S1). U in the cores was low to moderate (25-685 ppm), with most values below $300 \mathrm{ppm}$. Th/U was moderate to high (0.2-1.5). In contrast, $U$ in the overgrowths was much higher (250-1120 ppm) and $\mathrm{Th} / \mathrm{U}$ mostly very low $(\leq 0.01)$. These compositions reflect the different geological conditions under which the zircon crystallised. The cores are mostly detrital zircon eroded from igneous sources; the overgrowths were formed in situ during post-depositional metamorphism.

Consistent with their diverse origins, the 54 zircon cores analysed had a wide range of $\mathrm{U}-\mathrm{Th}-\mathrm{Pb}$ isotopic compositions. Most analyses were concordant or nearly so within analytical uncertainty (the few exceptions showed evidence of significant loss of radiogenic $\mathrm{Pb}$ ), but the $\mathrm{Pb}$ isotopic ages ranged from 3.53 to $1.82 \mathrm{Ga}$ (Fig. 7a). The distribution of ages was not uniform, however. Most of the ${ }^{207} \mathrm{~Pb} /{ }^{206} \mathrm{~Pb}$ ages (ca. 65\%) were in the range $2.1-1.9 \mathrm{Ga}$, and there were minor clusters at ca. 1.85 and $2.7 \mathrm{Ga}$. When the ${ }^{207} \mathrm{~Pb} /{ }^{206} \mathrm{~Pb}$ ages were plotted as a relative probability histogram (Fig. 8), it was evident that the large cluster at 2.1-1.9 Ga was a composite of several groups. As the analytical uncertainties overlap, the most objective, although non-unique, way to estimate the ages of those groups is by mixture modelling (Sambridge and Compston, 1994). That modelling identifies three main groups that account for about $65 \%$ of the analyses in the cluster. They have mean ages of $2050 \pm 15,1990 \pm 25$ and $1965 \pm 15$ (95\% c.l.) Ma, respectively. There is a minor group at $1915 \pm 30 \mathrm{Ma}$. The cluster of 8 analyses at about $1.85 \mathrm{Ga}$ possibly consists of two age groups, $1870 \pm 20$ and $1830 \pm 35 \mathrm{Ma}$. Of the 8 analyses in the ca. $2.7 \mathrm{Ga}$ group, only 5 have the same ${ }^{207} \mathrm{~Pb} /{ }^{206} \mathrm{~Pb}$ age within analytical uncertainty, $2709 \pm 15$ Ma.

The isotopic compositions of the overgrowths are very different. Although there is a relatively small range of ${ }^{207} \mathrm{~Pb} /{ }^{206} \mathrm{~Pb}$ ages $(1.85-1.76 \mathrm{Ga})$, the ${ }^{206} \mathrm{~Pb} /{ }^{238} \mathrm{U}$ and ${ }^{208} \mathrm{~Pb} /{ }^{232} \mathrm{Th}$ ages are extremely scattered (1.84-0.50 and 3.33-0.02 Ga, respectively, Fig. 7a). The relative uniformity of $\mathrm{Pb}$ isotopic compositions, but wide ranges in parent/daughter ratios, is evidence that, unlike the zircon cores, the overgrowths have been affected by severe, recent isotopic disturbance. Possibly the $\mathrm{Pb}$ loss is a consequence of recent low temperature alteration that also resulted in sericitisation of the plagioclase.

The only reliable way to estimate the age of the overgrowths is from the highest ${ }^{207} \mathrm{~Pb} /{ }^{206} \mathrm{~Pb}$ values. Seven of the eight ${ }^{207} \mathrm{~Pb} /{ }^{206} \mathrm{~Pb}$ 

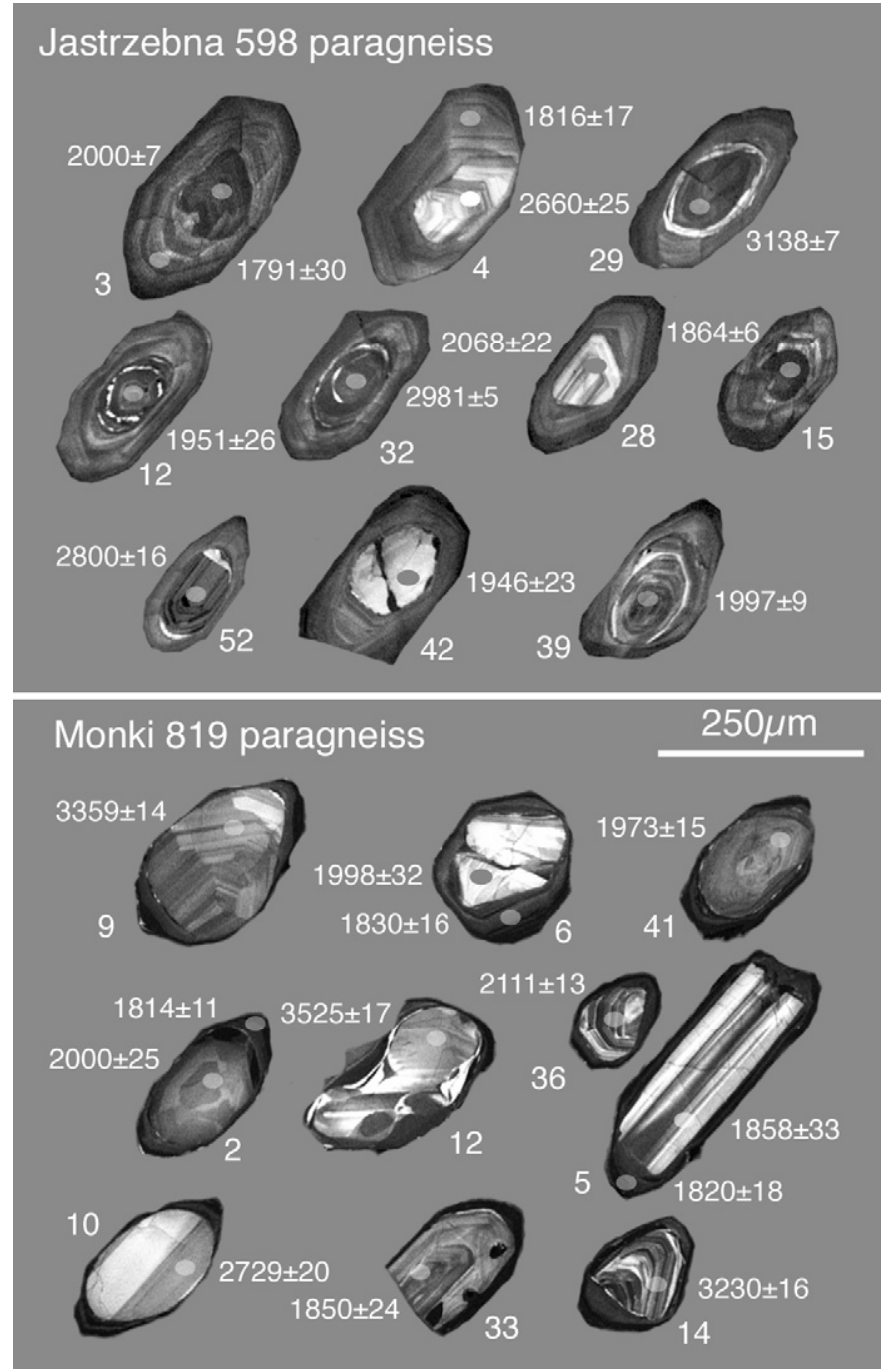

Fig. 6. Cathodoluminescence images of selected zircon grains from paragneiss samples Monki 819 and Jastrzebna 598 (age uncertainties $1 \sigma$ precision estimates).

values are equal within uncertainty, giving a weighted mean age of $1824 \pm 14 \mathrm{Ma}$, which is the best estimate of the age of post depositional metamorphism of this rock. This age is also within uncertainty of the age of the youngest cores, consistent with the time interval between deposition and metamorphism being less than about $38 \mathrm{Ma}$, the $95 \%$ c.l. uncertainty in the age difference.

\subsection{Paragneiss Jastrzebna 598 zircon}

The sample from the Jastrzebna core selected for zircon analysis was a relatively homogeneous cordierite-sillimanite gneiss from a depth of $598 \mathrm{~m}$. The zircon occurred as large (80-200 $\mu \mathrm{m}$ diameter), light grey-brown, mostly stubby subhedral to euhedral grains with fractured, inclusion-rich cores and clear, inclusion-free overgrowths. The crystal faces were well developed on some grains, but most were slightly scalloped, indicating partial dissolution after the last phase of crystal growth. CL imaging showed that all grains consisted of a zircon core surrounded by an overgrowth, commonly more than $50 \mu \mathrm{m}$ thick near the crystal terminations. The cores ranged from euhedral crystals to crystal fragments to grains that were strongly rounded. Zoning in the cores was varied, ranging from simple oscillatory zoning to chaotic zoning, to no zoning at all. Many cores showed the effects of recrystallisation, and the boundary between the cores and overgrowths commonly was marked by a very thin, discontinuous layer of strongly luminescent zircon. The overgrowths, in contrast, had a very similar texture on all grains. They were moderately luminescent and all had weak oscillatory zoning.

The 49 cores analysed mostly had low to moderate $U$ and Th contents (40-1050 and 20-550 ppm, respectively). Three cores had somewhat higher $U(1530-1780 \mathrm{ppm})$. Th/U ranged from low to high (0.05-2.7). Consistent with the range of chemical compositions, there was a wide range of isotopic compositions. With few exceptions, the $\mathrm{U}-\mathrm{Pb}$ isotopic analyses were concordant or nearly concordant, but the ${ }^{207} \mathrm{~Pb} /{ }^{206} \mathrm{~Pb}$ apparent ages ranged from ca. 3.14 to $1.83 \mathrm{Ga}$ (Fig. 7b). Most of the cores (ca. $60 \%$ ) had ${ }^{207} \mathrm{~Pb} /{ }^{206} \mathrm{~Pb}$ ages in the range $2.1-1.9 \mathrm{Ga}$. There was a much smaller cluster of ages (ca. $20 \%$ ) in the range $2.8-2.6 \mathrm{Ga}$.

As in Monki 819, the cluster of 33 Paleoproterozoic grains is clearly composite in age (Fig. 7b). Mixture modelling suggests that there are three main age groups, at $2035 \pm 12,1995 \pm 16$ and $1970 \pm 18$ (95\% c.l.) Ma. There is a minor group at $1920 \pm 20 \mathrm{Ma}$ and two of the three youngest grains have an age of ca. $1.86 \mathrm{Ga}$. Of the 10 analyses in the late Archean group, only five have the same ${ }^{207} \mathrm{~Pb} /{ }^{206} \mathrm{~Pb}$ age within analytical uncertainty, $2690 \pm 12 \mathrm{Ma}$.

In contrast to Monki 819, all the analyses of overgrowths are tightly clustered close to the concordia (Fig. 7b). There is a small range in ${ }^{207} \mathrm{~Pb} /{ }^{206} \mathrm{~Pb}$, however (MSWD $=1.8$ ). Omitting the lowest value leaves six analyses that give a mean age of $1841 \pm 14 \mathrm{Ma}$, just within error of the mean ${ }^{207} \mathrm{~Pb} /{ }^{206} \mathrm{~Pb}$ age of the overgrowths from Monki $819(1824 \pm 14 \mathrm{Ma})$.

\subsection{Paragneiss Jastrzebna 598 monazite}

Jastrzebna paragneiss 598 contained a small amount of monazite. It occurred as small (ca. $100 \mu \mathrm{m}$ diameter), subhedral, clear, equant, orange-yellow grains with very few inclusions and some poorly preserved crystal faces. Six grains were analysed for $\mathrm{U}-\mathrm{Th}-\mathrm{Pb}$ isotopes. Although the grains had a moderate range of $U$ and Th contents (920-2950 and 79,000-104,000 ppm, respectively), all the $\mathrm{U}-\mathrm{Pb}$ isotopic compositions were the same within analytical error, giving a weighted mean ${ }^{207} \mathrm{~Pb} /{ }^{206} \mathrm{~Pb}$ age of $1827 \pm 20 \mathrm{Ma}$, just within error of the mean age measured on the zircon overgrowths from the same rock (Table S1), and the same as the mean ${ }^{207} \mathrm{~Pb} /{ }^{206} \mathrm{~Pb}$ age of the overgrowths from Monki 819 .

\section{Implications of the analyses-similarities to Svecofennian metasediments}

The possibility of a link between the covered basement of NE Poland and the Paleoproterozoic crust that extends across the Baltic Shield and into southern Greenland was first mooted by Claesson et al. (Claesson, 1999; Claesson and Ryka, 1999; Claesson et al., 2001) based primarily on regional similarities in zircon $\mathrm{U}-\mathrm{Pb}$ and whole-rock Nd model ages. The results of the present study provide evidence for a much more specific link between the metasediments of the buried Polish basement and the exposed Svecofennian, such as the metasediments of southern Finland.

\subsection{Similarities in detrital zircon ages}

Studies of sediment provenance on the basis of populations of detrital zircon ages require the dating of large numbers of grains. If a suite of analyses is to have a 95\% chance of sampling all detrital components with a relative abundance of $5 \%$ or more, then it is necessary to date at least 60 (Fedo et al., 2003) and possibly 120 (Vermeesh, 2004) randomly selected crystals. Data sets with less analyses risk missing minor components and misrepresenting the relative abundances of even the major components (Andersen, 2005). Effective studies of detrital zircon populations (Table 3 ) have 

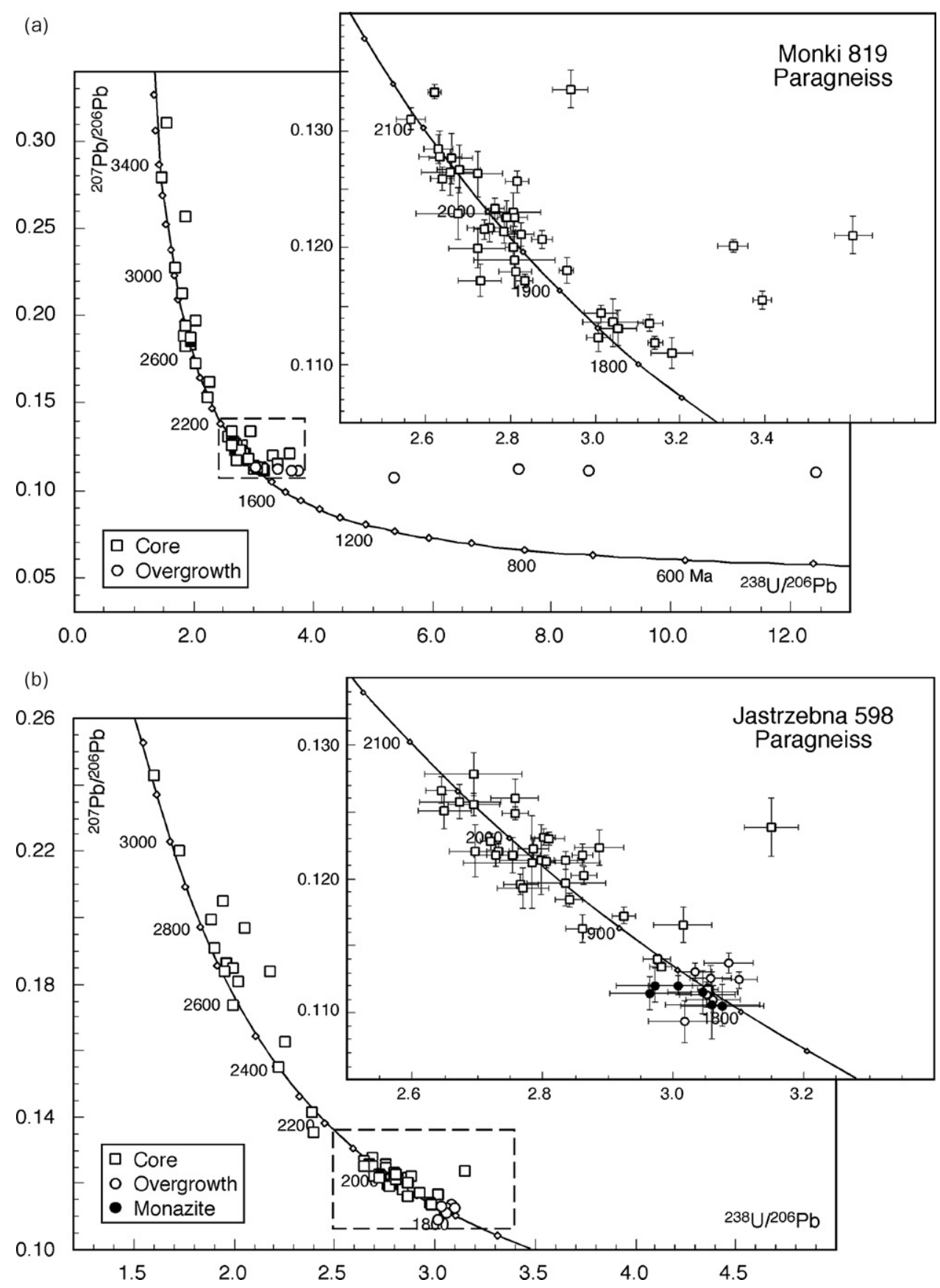

Fig. 7. Concordia diagrams showing zircon U-Pb analyses from (a) Monki 819; (b) Jastrzebna 598.

only been feasible since the development of techniques for rapid in situ U-Pb micro-isotopic analysis; high resolution SIMS and laser ICP-MS.

Following early SIMS work on Finnish Svecofennian metasediments by Huhma et al. (1991), which demonstrated the presence of zircon from both Paleoproterozoic and Archean sources, Claesson et al. (1993) carried out a more wide-ranging SIMS survey of detrital zircon ages from several sites throughout the exposed Svecofennian metasediments in Sweden and Finland. A feature of their measurements of about 140 zircon ages was the broad similarity between the populations from each site. The samples were dominated (ca. 70\%) by Paleoproterozoic zircon with ages in the narrow range 2.1-1.9 Ga, the remainder being Archean (mostly 3.0-2.6 Ga). There was a marked lack of zircon from the intervening period $(2.6-2.1 \mathrm{Ga})$. The oldest grains were $3.44 \mathrm{Ga}$ (from the Tampere
Schist Belt) and 3.31 Ga (from Västervik). It was concluded that most of the zircon came from the nearby Baltic Shield, the Paleoproterozoic component from newly mantle-derived crust and the Archean component from older rocks in the northeast of the East European Craton. It was also considered possible that the oldest components in the metasediments in Sweden might have originated from 'unknown' Archean sources to the southwest. This interpretation assumes that these older terranes were exposed at the time, which might not have been the case (Bogdanova, personal communication, 2009).

Very similar results have been obtained in subsequent more detailed studies. In their work on the Svecofennian metasediments from central and southern Finland, Lahtinen et al. (2002) again found that the detrital zircon from different metasedimentary units was dominated by Paleoproterozoic $(2.10-1.86 \mathrm{Ga})$ grains, with a 

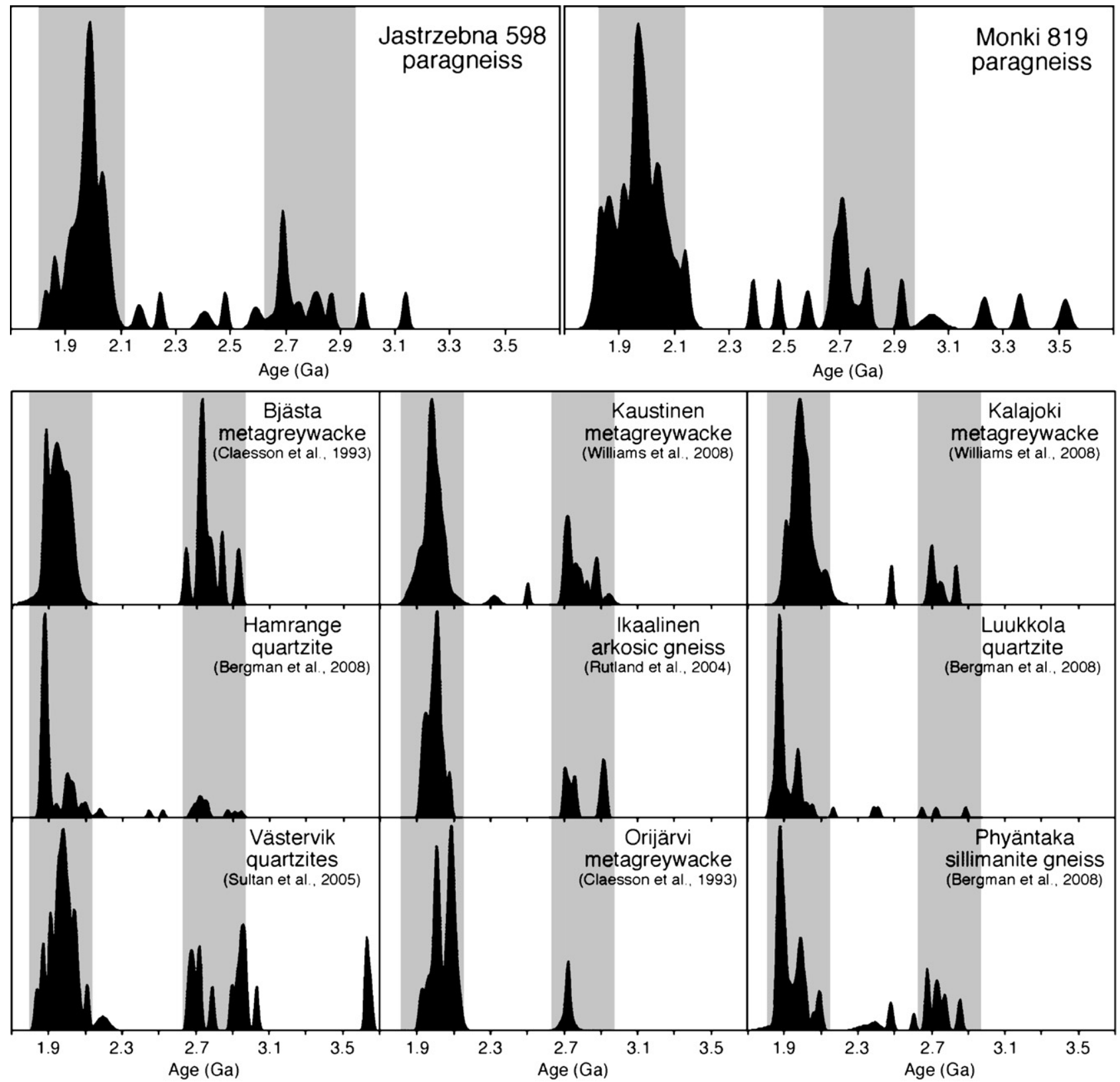

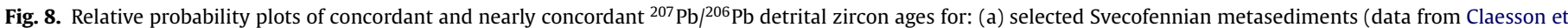
al., 1993; Rutland et al., 2004; Sultan et al., 2005; Williams et al., 2008; Bergman et al., 2008) and for (b) Monki 819, (c) Jastrzebna 598.

marked scarcity of ages between 2.6 and $2.1 \mathrm{Ga}$. The relative proportion of the Archean component in each sample differed widely, ranging from undetected up to ca. 50\% of the grains. A similar detrital zircon population was found in a paragneiss inclusion in a ca. $1.93 \mathrm{Ga}$ gneissic tonalite. The largest amounts of Archean zircon, mostly 2.75-2.65 Ga, were found in some samples from NE Finland close to the margin of the Karelian Craton. It was proposed that one source of the Paleoproterozoic detritus might have been the Sarmatian segment.

Rutland et al. (2004), in their study of Svecofennian metasediments from southern Finland, also found that the detritus was dominated by zircon of Paleoproterozoic age (2.0-1.9 Ga) and that the relatively rare Archean component was mostly 2.75-2.65 Ga old, and none older than $2.95 \mathrm{Ga}$. As elsewhere, there was a scarcity of grains between 2.6 and $2.1 \mathrm{Ga}$. The emphasis in that study, however, was on the metamorphic history of the gneisses. It was argued that there were two sedimentary sequences, deposited before and after a major $1.92 \mathrm{Ga}$ tectonothermal event, respectively. The same ranges of detrital zircon ages and further evidence for the subdivision have since been found in the Svecofennian of Ostrobothnia, NW Finland (Williams et al., 2008). The concept of two main Svecofennian sequences was first proposed by Sederholm (1897), and revived following some of the first work on detrital zircon (Claesson et al., 1993; Welin et al., 1993).

In their later study of detrital zircons from the Västervik area, Sultan et al. (2005) again found a mixture of Archean (ca. 25\%) and Paleoproterozoic (ca. 75\%) components. Their 41 mostly concordant analyses yielded $\mathrm{Pb}-\mathrm{Pb}$ ages of ca. 3.64, 3.03-2.95, 2.72-2.69, 2.12-1.87 and $1.84 \mathrm{Ga}$. Sultan et al. (2005) noted that rocks with ages similar to the oldest group in the Västervik Basin samples were rare in the Baltic Shield. Rocks with ages of $2.2-1.9 \mathrm{Ga}$ are present, for example, in northern Finland, but they are mostly of mafic compositions and would not contribute significant amounts of detrital zircon grains. It was therefore suggested that the nearest 
Table 3

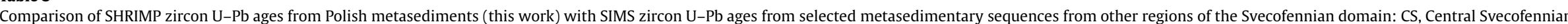
Orogen; SS, Southern Svecofennian Orogen; TSB, Tampere Shist Belt; VMB, Vammala Migmatite Belt; BMD, Bergslagen mining district; SD, Skellefte district; VB, Västervik Basin.

\begin{tabular}{|c|c|c|c|c|c|c|c|}
\hline Location & $\begin{array}{l}\text { Number of } \\
\text { samples:spots }\end{array}$ & Sediment type & $\begin{array}{l}\text { Max deposition } \\
\text { age (Ga) }\end{array}$ & $\begin{array}{l}\text { Oldest grain:group } \\
(\mathrm{Ga})\end{array}$ & Main group (Ga) & $\begin{array}{l}\text { Metam orphic } \\
\text { events (Ga) }\end{array}$ & Igneous activity (Ga) \\
\hline Ostrobothnia Kalajoki-1a & $1: 69$ & Metagreywacke & 1.95 & 2.84 & $2.05-1.95$ & 1.92 & \\
\hline Ostrobothnia Kannus-1 ${ }^{\text {a }}$ & $1: 16$ & Metagreywacke & & 2.59 & $2.00-1.90$ & 1.921 .85 & 1.90: Kannus-2 \\
\hline Ostrobothnia Nivala-1 ${ }^{\mathrm{a}}$ & $1: 36$ & Migmatised paragneiss & 1.90 & $2.91: 2.72$ & $2.03-1.90$ & 1.88 & \\
\hline Ostrobothnia Kalajoki-2a & $1: 40$ & Metagreywacke & 1.91 & $2.86: 2.65$ & $2.00-1.91$ & & \\
\hline Ostrobothnia Nivala-2a & $1: 60$ & Metagreywacke & 1.95 & 2.72 & $2.05-1.95$ & 1.911 .88 & \\
\hline Ostrobothnia Kaustinen-1 $1^{\mathrm{a}}$ & $1: 77$ & Metagreywacke & 1.90 & $2.95: 2.88$ & $2.06-1.90$ & & \\
\hline Average Bothnian Basin ${ }^{\mathrm{b}}$ & $8: 136$ & $\begin{array}{l}\text { Metagreywackes } \\
\text { quartzites }\end{array}$ & $\begin{array}{l}1.87 \text { Los qtzite, } \\
\text { Sweden }\end{array}$ & 3.44 Tampere & $2.12-1.91$ & & \\
\hline Average C Svecofenn. (Finland) & $4: 77$ & $\begin{array}{l}\text { Metagreywackes } \\
\text { arkoses (mature) }\end{array}$ & $1.92-1.88$ & $3.04: 2.73-2.67$ & $\begin{array}{l}\text { Upper } 1.90-1.88 \text {, } \\
\text { lower } 2.02-1.93\end{array}$ & & 1.89-1.88: CF-granitoid \\
\hline Average S Svecofenn. (Finland) & $5: 75$ & Mature-less mature & 1.86 & $3.15: 2.74-2.67$ & $2.11-2.02$ & 1.931 .88 & \\
\hline N Berslagen $(S \text { Sweden })^{\mathrm{d}}$ & $3: 34$ & $\begin{array}{l}\text { Sill gneiss crd gneiss } \\
\text { (high grade) }\end{array}$ & $1.92-1.91,1.85$ & 2.78 & $\begin{array}{l}2.00-1.90 \\
1.89-1.87\end{array}$ & $\mathrm{~N}: 1.87 \mathrm{~S}: 1.831 .80$ & Plutonic 1.89 , volcanic 1.89 \\
\hline Hamrånge (Berslagen)e & $1: 77$ & Quartzite (mature) & 1.86 & $2.94: 2.90-2.70$ & $\begin{array}{l}1.89-1.87 \\
2.09-1.99\end{array}$ & $1.88-1.86$ & $\begin{array}{l}\text { 1.89: dacite, } 1.86 \text { : Ljusdal } \\
\text { batholith }\end{array}$ \\
\hline Tiirismaa (S Finland) ${ }^{\mathrm{e}}$ & $1: 28$ & Quartzite (mature) & 1.85 & $3.32: 2.78-2.71$ & $1.91-1.87$ & $1.83-1.82$ & \\
\hline Pyhäntaka (S Finland) ${ }^{\mathrm{e}}$ & $1: 60$ & Qtz-sill gneiss & 1.86 & $2.86: 2.79-2.71$ & $\begin{array}{l}1.89-1.87 \\
2.09-1.99\end{array}$ & & \\
\hline Luukkola (S Finland) $^{\mathrm{e}}$ & $1: 57$ & Quartzite (mature) & 1.84 & 2.89 & $1.89-1.87$ & & \\
\hline Västervik $(\mathrm{S} \text { Sweden })^{\mathrm{f}}$ & $3: 41$ & Quartzites (mature) & $1.85(1.84)$ & $\begin{array}{l}3.64: 3.03-2.95 \\
2.72-2.69\end{array}$ & $2.11-1.87$ & 1.86 & 1.86: Loftahamar granite \\
\hline Jastrzebna (NE Poland) ${ }^{\mathrm{g}}$ & 1:56 & $\begin{array}{l}\text { crd-sill gneiss } \\
\text { (immature) }\end{array}$ & 1.86 & $3.14: 2.70$ & $2.05-1.86$ & 1.83 & 1.83: Jastrzebna pegmatite \\
\hline Monki (NE Poland)g & $1: 62$ & $\begin{array}{l}\text { bt-ms gneiss (less } \\
\text { mature) }\end{array}$ & 1.83 & $3.53: 2.71$ & $2.11-1.83$ & 1.82 & 1.83: Monki orthogneiss \\
\hline
\end{tabular}

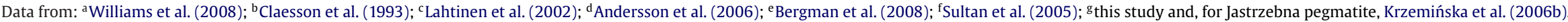


area of possible source rocks for the metasediments might be a part of the Sarmatia Block like that now exposed in Ukraine, to the SE of present Fennoscandia. Following additional work, Claesson and Sultan (2008) again proposed the Baltic Shield as a possible source for the Västervik metasediments, with a contribution from 1.85 to $1.80 \mathrm{Ga}$ arc volcanic rocks of the Oskarshamn-Jönköping Belt, SE Sweden.

The recent SIMS U-Pb study of detrital zircon from metasandstones related to the upper parts of Svecofennian sequences in southeastern Finland and east-central Sweden (Luukkola, Pyhäntaka, Tiirismaa and Hamrånge) yielded a multimodal age distribution with three main populations at 2.95-2.60, 2.10-1.95 and $1.92-1.85 \mathrm{Ga}$ (Bergman et al., 2008), which are broadly similar to previously reported detrital zircon ages from that part of Fennoscandia. This age distribution suggests the former existence of several intraorogenic sedimentary basins between two main orogenic events in the time interval 1.86-1.83 Ga. Bergman et al. (2008) suggested that the principal source area for the detritus was nearby, the Ljusdal Batholith and Arc Complex of western and southern Finland.

The remarkable regional similarities in the detrital zircon age distributions in the Svecofennian metasediments of Sweden and Finland are apparent when the ages are plotted (Fig. 8) on relative probability diagrams (Dodson et al., 1988). The dominant feature of all the metasediments is the high relative abundance of $2.1-1.9 \mathrm{Ga}$ Paleoproterozoic zircon, the presence of a subsidiary population at $2.9-2.7 \mathrm{Ga}$ (highlighted by grey shading) and the lack of zircon with ages between 2.6 and $2.1 \mathrm{Ga}$. Early Archean zircon is also very scarce. The closest matches to the metasediments of Poland are the metasediments from Kaustinen, Pyhäntaka and the Västervik Basin (Figs. 8 and 9).

Sediments with similar detrital zircon ages have been reported from several other Paleoproterozoic metasediments from Finland, the Kola Peninsula, NW Scotland and Greenland (Claesson, 1999; Zhao et al., 2002; Tuisku and Huhma, 2006). Most of those metasediments are interpreted to have been deposited in magmatic arc environments. Evidence of arc-related volcanic and plutonic rocks of similar or the same age range has been reported from both northern Finland and Sweden (e.g. the Lapland Granulite Belt; Claesson, 1999; Zhao et al., 2002; Tuisku and Huhma, 2006).

\subsection{Late Paleoproterozoic metamorphism}

Several Paleoproterozoic metamorphic events have been identified in the EEC by $\mathrm{U}-\mathrm{Pb}$ dating of zircon overgrowths and confirmed by the dating of monazite. The rocks in the central and eastern parts of the Fennoscandian Shield have been subjected to several regional low-pressure metamorphic episodes ranging in grade from upper greenschist to amphibolite facies. The older (Svionian; Rutland et al., 2004) greywacke sequences were affected by early metamorphism, producing a high-grade schistosity. This $1.92 \mathrm{Ga}$ post-depositional event has been recognised in the Vammala Migmatite Belt (VMB, Rutland et al., 2004) and in Ostrobothnia (Williams et al., 2008). The widespread Early Svecofennian deformations were somewhat diachronous (Table 3 ). The next regional event, recorded in the post-1.92 Ga (Bothnian) volcanics and greywackes from both Sweden and Finland was the major metamorphic event in the region. This Middle Svecofennian deformation, leading to migmatisation in the VMB, has been dated by several isotopic methods (Mouri et al., 1999; Rutland et al., 2004) at ca. $1.88 \mathrm{Ga}$ and correlates with metamorphism in the Tampere Schist Belt (TSB), the Skellefte District and N-Berslagen (Andersson et al., 2006). In central Sweden (e.g. the Västervik and Berslagen areas), migmatisation and $\mathrm{D}_{1}$ deformation related to the major event in the region occurred slightly later, at ca. $1.86 \mathrm{Ga}$ (e.g. Korsman et al., 1984, 1988; Beunk and Page, 2001; Skiöld and
Rutland, 2006; Högdahl and Sjöström, 2006). The southern part of the Svecofennian Domain was also affected by an event at about $1.82-1.80 \mathrm{Ga}$, possibly related to the emplacement of late-orogenic S-type granites that crosscut the older migmatites (Claesson and Lundquist, 1995). This age has not yet been confirmed by U-Pb dating, but it is possible that the ca. 1.83 Ga metamorphism of the Polish metasediments dated by the present study was related to this event.

\subsection{Petrological similarities}

The nature and composition of the Svecofennian metasediments exposed in the Baltic Shield (Fig. 9) differs regionally depending on the source material and metamorphic grade. The well-known Svecofennian metasedimentary rocks in the TSB are metagreywackes, consisting of quartz, plagioclase, microcline and volcanic rock fragments in a micaceous matrix. These metasediments have been interpreted as turbidites deposited as submarine fans either in a fore-arc (Ojakangas, 1986; Lahtinen, 1996), or marginal (Rutland et al., 2004), basin. Late metamorphism, ranging from greenschist to lower amphibolite facies, was coeval with widespread intrusion of granitoids at 1.89-1.87 Ga (Kilpeläinen et al., 1994). The metasediments in the VMB have a higher content of mafic components. They are characterised by both plagioclase-quartz-biotite (with minor garnet) and K-feldspar-sillimanite-muscovite metamorphic assemblages (Rutland et al., 2004). The metasediments in the Southern Svecofennian subprovince (Fig. 1) were derived from less mature source rocks (Lahtinen et al., 2002). These sediments consist of both immature greywackes with a large volcanogenic component and mature quartzites, reflecting derivation from both unweathered and weathered basement.

Related metasedimentary rocks are well exposed in the Berslagen mining district of central Sweden (Fig. 9). The lowermost part of the sequence is dominated by medium-grained arkoses of continental derivation (Kumpulainen et al., 1996). To the north, in the Skellefte district, the sediments are predominantly metamorphosed turbiditic mud- and sandstones, intercalated with mafic volcanic rocks. They are intruded by several generations of granite (Bergman et al., 1996; Billström and Weihed, 1996). Both areas are metamorphosed from greenschist to amphibolite facies.

The southernmost exposures of well-documented Svecofennian metasediments are in the Västervik Basin of southern Sweden. The various lithologies include arc-related garnet-sillimanite gneisses (Beunk et al., 1996), haematitic quartzite (Sultan et al., 2005; Claesson and Sultan, 2008) and volcanic rocks. The sequence is intruded by gabbros and granitoids (Beunk et al., 1996; Beunk and Page, 2001).

The few basement metasediments sampled by drilling of the Mazowsze Domain are mineralogically very similar to those in the Baltic Shield exposures. The metasediments consist of biotite and sillimanite-cordierite gneisses, locally strongly laminated, with intercalations of volcanogenic material, metamorphosed up to amphibolite grade. Much of the sediment is relatively immature, with high contents of plagioclase. The Mazowsze metasediments also are intruded by mid to late Paleoproterozoic (1.83-1.82 Ga) granites (Krzemińska et al., 2006b, 2007; Wiszniewska et al., 2007), although they are slightly younger than those in Sweden and Finland (Korja et al., 2006). This combination of low to medium grade immature metasediments, volcanogenic amphibolites and later granitoids is typical of the classical Svecofennian sequences in Finland and Sweden.

\subsection{Geochemical similarities}

The REE, high field strength elements (HFSE), Th and Sc are all valuable indicators of the average source composition of clastic sediments (McLennan et al., 1990). Trace element ratios such 


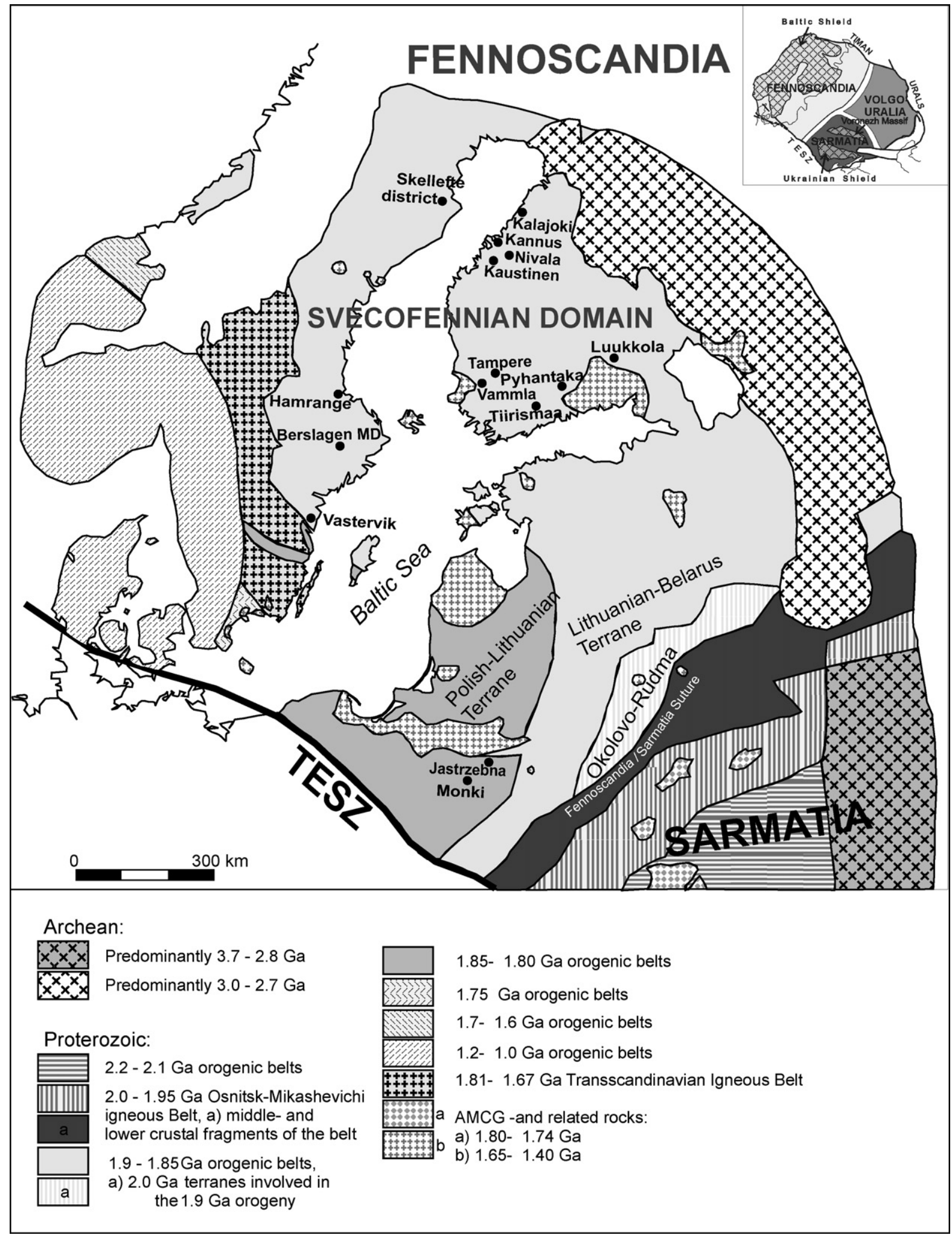

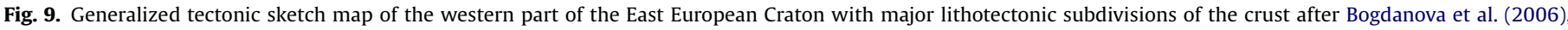
showing locations of the Svecofennian metasediments within both the 1.90-1.85 and 1.85-1.80 Ga orogenic belts (faults not shown).

as $\mathrm{Th} / \mathrm{Sc}, \mathrm{La} / \mathrm{Sc}$ and $\mathrm{Ti} / \mathrm{Zr}$ have been used to discriminate between sediments deposited in different tectonic settings, and in particular to discriminate between sediments deposited in oceanic and continental environments (Bhatia and Crook, 1986). For each of these ratios, there is a close similarity between the values and ranges found in the Mazowsze Domain metasediments (Table 2) and those observed in the metasediments of the exposed Svecofennian (Fig. 3). In each case, however, the scatter observed in the Jastrzebna samples is slightly larger (Fig. 5), consistent with the detritus forming those metasediments having been less well mixed. The values observed for each of the ratios are very similar to those of average upper continental crust (Taylor and McLennan, 1985), and 

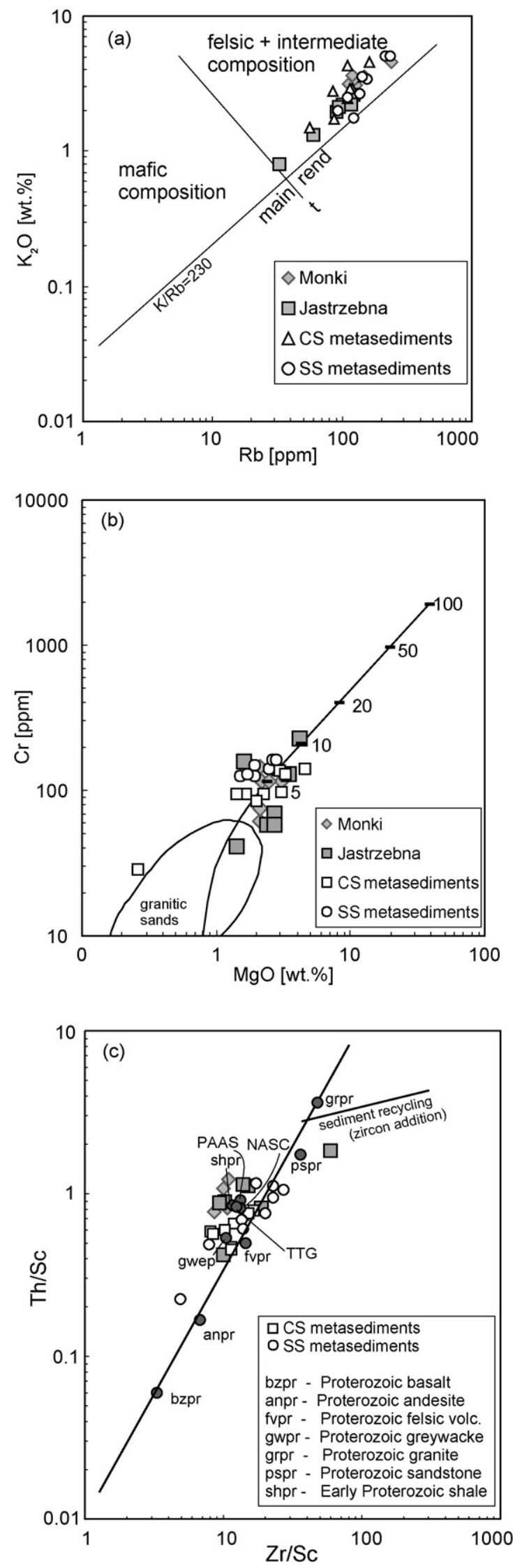

consistently indicate deposition in a continental island arc setting (Lahtinen, 2000; Lahtinen et al., 2002). They are, however, slightly offset towards values found in sediments deposited on active continental margins, suggesting an above-average continental input to the system (Fig. 5).

The REE in metasediments also reflect the chemical composition of their source rocks, but must be interpreted in the knowledge that the REE can be mobile (Rollinson, 1994). The Svecofennian metasediments have REE patterns extremely similar to PAAS (Taylor and McLennan, 1985), as do the metasediments from Monki (Fig. 4). The metasediments from Jastrzebna, however, although having the same LREE levels, consistently have a marked relative depletion in the HREE. Such a depletion is the main feature of the REE in TTG suite granitoids (Martin et al., 2005), and probably indicates the derivation of much of the Jastrzebna sediment from this rock type. This conclusion is supported by the relatively high plagioclase content of the Jastrzebna metasediments, which is also reflected in their weakly negative to positive Eu anomalies (Fig. 4b).

The Svecofennian and Mazowsze Domain metasediments are also very similar to one another in major element composition. Not only are they indistinguishable in characteristics such as $\mathrm{TiO}_{2}$, $\mathrm{Fe}_{2} \mathrm{O}_{3}+\mathrm{MgO}$ and $\mathrm{Al}_{2} \mathrm{O}_{3} / \mathrm{SiO}_{2}$ (Table 1 ), they also have the same indices of chemical alteration (CIA: Lahtinen et al., 2002). The average composition of the source rocks and the major element fractionations that took place during erosion, transport and deposition in both cases must have been very similar.

Trace and major elements in combination provide yet another basis for comparison, particularly of the nature of the source materials. Both the Svecofennian and Mazowsze Domain metasediments (Fig. 10) have very similar and relatively high $\mathrm{K}_{2} \mathrm{O}$ and $\mathrm{Rb}$ contents, and a narrow range of $\mathrm{K}_{2} \mathrm{O} / \mathrm{Rb}$ close to the 'Main Trend' for igneous suites defined by Shaw (1968). The $\mathrm{K}_{2} \mathrm{O}$ and $\mathrm{Rb}$ contents reflect derivation from a source of felsic to intermediate, not mafic, composition. The $\mathrm{Cr}$ and $\mathrm{MgO}$ contents, however, which again are similar in both regions, are higher than expected for modern granitic sands (Van de Kamp and Leake, 1995), reflecting the presence in both sediment packages of an ultramafic component (ca. 5-10\%). In combination, Th/Sc and $\mathrm{Zr} / \mathrm{Sc}$ provide an indication of both source rock composition and degree of sediment recycling (McLennan et al., 1993). As for other parameters, the Svecofennian and Mazowsze Domain metasediments are very similar. Their compositions lie slightly above the trend of volcanic rock compositions, in the same region as PAAS, the North American Shale Composite (NASC), Proterozoic shales (shpr), Proterozoic greywacke (gwep)(Condie, 1993) and TTG (Fig. 10c). They are quite distinct from Proterozoic felsic volcanics and granites, and show no evidence for the $\mathrm{Zr}$ enrichment that occurs in sediments that have been recycled.

\section{Provenance of the metasediments}

The provenance of the Svecofennian metasediments is a longstanding question that has yet to be fully resolved. Most of the exposed Svecofennian crust initially was considered to have formed in the period 1.90-1.86 Ga (Gaal and Gorbatschev, 1987). The oldest Svecofennian intrusives are trondhjemites and tonalites in eastern

Fig. 10. Chemical features of the Monki and Jastrzebna paragneisses: (a) distribution of $\mathrm{K}_{2} \mathrm{O}$ and $\mathrm{Rb}$ in metasediments relative to the "main trend" of Shaw (1968), suggesting the presence of igneous material of felsic to intermediate composition. (b) $\mathrm{Cr}-\mathrm{MgO}$ correlation plot showing the proportion of ultramafic detritus in metasediments. Mixing line for "granitic" and ultramafic detritus and field of the modern "granitic sands" from Van de Kamp and Leake (1995). (c) Binary Th/Sc versus Zr/Sc plots (after McLennan et al., 1993). Average rock compositions after Condie (1993) show potential sources and similarities. Note the geochemical features of the central and south Svecofennian immature and mature metasediments (Lahtinen et al., 2002). Symbols for Monki and Jastrzebna sediments as in (a) and (b). 
Finland and northern Sweden (Korsman et al., 1984; Skiöld et al., 1993; Korja et al., 2006). Early Nd data indicated, however, that the Svecofennian metasediments must contain an older component, possibly up to 50\% in the Swedish metasediments (Patchett et al., 1987; Claesson, 1987). The presence of that component was confirmed by single-crystal U-Pb dating of detrital zircons from the metasediments of Sweden and Finland (Huhma et al., 1991; Claesson et al., 1993), some zircons having ages up to $3.4 \mathrm{Ga}$. The dominant zircon age group, however, was 2.1-1.9 Ga, a generation of rocks not known within the Baltic Shield. It was assumed that the Archean component was derived from the Archean craton in the NE of the Baltic Shield, and possibly also from an unknown landmass once located to the SW of the Bothnian Basin.

Several subsequent studies have confirmed that the pattern of detrital ages first found by Huhma et al. (1991) is a feature of the Svecofennian metasediments throughout Finland and Sweden (e.g. Claesson et al., 1993; Lahtinen et al., 2002; Rutland et al., 2004; Sultan et al., 2005; Bergman et al., 2008; Williams et al., 2008). The relative abundance of the various components differs from place to place, but all metagreywacke samples are characterised by a major population of $2.1-1.9 \mathrm{Ga}$ zircon, a scarcity of grains with ages in the range $2.6-2.1 \mathrm{Ga}$, a cluster of ages at about 2.9-2.7 Ga, and rare grains up to $3.5 \mathrm{Ga}$ (Fig. 8). This age distribution is not matched by any presently known terrane in the Baltic Shield, although meta-igneous mafic and felsic granulites, as well as trondhjemite gneisses, up to ca. $3.5 \mathrm{Ga}$ have been found in the Pudasjärvi Granulite Belt, NE Finland (Mutanen and Huhma, 2003).

It has also been discovered that metasediments with lithological and isotopic characteristics very similar to the Svecofennian metasediments of Finland and Sweden are present further to the SE in the basement of the EEC. Puura and Huhma (1993), for example, in their Nd isotopic study of representative East Baltic granulites from southern Estonia, measured model ages between 2.18 and $2.08 \mathrm{Ga}$, concluding that, like the Svecofennian crust in Finland and Sweden, the granulites originated from Paleoproterozoic, not Archean sources. Mansfeld (2001) concluded from his study of basement metasediments in Estonia, Latvia and west Lithuania, that there was a continuous Svecofennian crustal province extending SE from Sweden across the Baltic Sea. He further postulated that the province might extend as far east as the Baltic-Belarus granulite belt, west of Sarmatia.

This suggestion was strongly supported by subsequent work by Claesson et al. (2001), who demonstrated, not only that the Precambrian basement between the Baltic and Ukrainian Shields was Proterozoic, not Archean, but also that the initial Nd isotopic compositions of the igneous rocks in that area are strikingly similar to those of igneous rocks in the Svecofennian Domain of the Baltic Shield, and the Nd compositions of the metasediments in the two regions are virtually the same. They proposed that the Svecofennian might represent terranes accreted to the western margin of Sarmatia, and importantly it was noted that the Osnitsk-Mikashevichi Igneous Belt (OMI) on the western edge of Sarmatia is dominated by $2.1-2.0 \mathrm{Ga}$ calc-alkaline plutonic rocks that might be the source of much of the Svecofennian detrital zircon. More recent work suggests that the age range is closer to $1.98-1.95 \mathrm{Ga}$ (ca. $2.1 \mathrm{Ga}$ being the age of major collision events within Sarmatia), although some rocks up to $2.00 \mathrm{Ga}$ are known (Bogdanova et al., 2006 and references within).

Following their study of Nd isotopes and detrital zircon ages from central and southern Finland, Lahtinen et al. (2002) reviewed the provenance problem in detail. They emphasised that the Svecofennian metasediments were derived simultaneously from both weathered and unweathered basement rocks, and active volcanic centres. The depositional environment must have been a large subsiding basin, possibly at a passive margin. Given that many of the metasediments are mid-fan turbidites, long-distance transport along a trench system was considered to be unlikely. The volume and extent of the metasediments implied derivation from a rapidly rising orogen, but once again the lack of potential source rocks of appropriate age (2.0-1.9 Ga) within the exposed Svecofennian orogen was emphasised, making derivation of the detritus from within that orogen highly unlikely.

Lahtinen et al. (2002) considered three main possibilities: (1) heavy erosion of the source rocks, leaving little behind at the present level of exposure, (2) derivation of the 2.0-1.9 Ga material from an accretionary wedge transported from an unknown source, and (3) derivation of the detritus from a nearby source later transported away by tectonic movements. None of these possibilities was particularly attractive, so others were also discussed. Metasediments in southern Greenland have a similar population of detrital zircons and metamorphic history to the Svecofennian metasediments (Nutman et al., 1999), so the rocks in both areas might have a common source. The Taltson magmatic zone in Canada contains an abundance of 2.0-1.9 Ga granitoids (Bostock and van Breeman, 1994), but the associated metasediments and the adjacent Rae Province are rich in zircon with ages in the range 2.6-2.1 Ga-the marked lack of such zircon in the Svecofennian metasediments makes their derivation from Paleoproterozoic rocks in western Canada highly unlikely. Lahtinen et al. (2002) tentatively suggested that the source of the metasediments might be Sarmatia.

The results of further work on the metasediments of the Västervik Basin (Sultan et al., 2005; Claesson and Sultan, 2008) and our work on the Proterozoic basement metasediments of central Poland reported here make derivation of the metasediments from western Sarmatia a very likely possibility. If we accept that Svecofennian metasediments extend into Poland beneath the Baltic Sea and through Latvia, Lithuania and western Belarus, then the sediments were probably deposited in a large marginal basin or basin complex (Rutland et al., 2004) that extended a considerable distance adjacent to the northwestern edge of the Sarmatian Craton.

The northwestern active continental margin of Sarmatia (Shumlyanskyy et al., 2006) is composed mostly of juvenile Paleoproterozoic crust. Except for several ca. 2.08-2.02 Ga granitoid bodies within the Volyn Domain (Claesson et al., 2006 and references therein), the predominant age of rocks in the large OMI belt is ca. 2.02-1.95 Ga (Bogdanova et al., 2006). The west Sarmatian terranes have been interpreted as the remains of a large Paleoproterozoic $(2.1-2.0 \mathrm{Ga})$ igneous province that would have been active immediately inboard of the basin at the same time as the sediments were being deposited (Claesson et al., 2006). Although at least part of the OMI is somewhat younger (Bogdanova et al., 2006), the belt might have been a major source for the 2.1-1.9 Ga zircon that dominates the detrital zircon population. It is also possible that the coeval TTGs of the ca. 2.0-1.9 Ga SE Fennoscandian Okolovo-Rudma Subterrane (Taran, 2001; Bogdanova et al., 2006) are part of a related igneous province. Further, post-tectonic granites with ages in the range $2.7-2.6 \mathrm{Ga}$ and slightly older high-grade metamorphic rocks are found in the western Ukrainian Shield (Claesson et al., 2006), providing a possibly source for the subordinate late Archean zircon population in the metasediments.

Older Archean components up to $3.6 \mathrm{Ga}$ are also found in the shield (Bibikova et al., 2000; Shcherbak et al., 2002). Sarmatia therefore contains all the components found in the Polish and northern Svecofennian metasediments. Further, 2.6-2.1 Ga was a period of tectonic quiescence in the shield, marked by the deposition of major banded iron formations (Bibikova et al., 1963), possibly explaining the lack of zircon of this age in the adjacent metasediments. Derivation of the Svecofennian metasediments primarily from the active margin of Sarmatia is also consistent with the conclusion by Sultan et al. (2005) that the turbidites of the Västervik Basin were derived from the south. 


\section{Conclusions}

This reconnaissance study of the age, provenance and chemical composition of metasediments recovered from deep boreholes in central NE Poland, close to the boundary between the Fennoscandian and Sarmatian Blocks, has shown that the Polish metasediments are remarkably similar, in many respects, to the Svecofennian metasediments exposed in Sweden and Finland. The Polish rocks are within the (1.85-1.80 Ga) Polish-Lithuanian Terrane (Bogdanova et al., 2006), the youngest Paleoproterozoic terrane of the Svecofennian Domain, whereas both the mature and immature metasediments from Finland and Sweden are part of the oldest crust $(1.93-1.85 \mathrm{Ga})$ exposed in that domain (Fig. 9). It is possible that the Polish, Finnish and Swedish metasediments are all part of a single basin or basin system that developed at the western margin of Sarmatia in the mid Paleoproterozoic (pre ca. $1.84 \mathrm{Ga}$ ).

This conclusion is based on the following evidence:

- Like the exposed Svecofennian metasediments, the Monki and Jastrzebna paragneisses are metamorphosed greywacke, shale or Fe-shale.

- The trace element and REE compositions of the Monki paragneiss are broadly similar to the compositions of metasediments from the central and southern Svecofennian domains. The chemical composition of Jastrzebna paragneiss reflects a higher proportion of TTG-related, unweathered components than in those rocks.

- Like the exposed Svecofennian metasediments, trace element discriminants (La-Th-Sc, Th-Sc-Zr) indicate an active continental margin or continental island-arc origin for the Polish metasediments.

- Like the exposed Svecofennian metasediments, the detrital zircon assemblage in the Polish metasediments is dominated by zircon 2.1-1.9 Ga old, with a subordinate population at 2.9-2.7 Ga and minor Archean components up to $3.5 \mathrm{Ga}$. There is also a marked lack of detrital zircon in the age range $2.6-2.1 \mathrm{Ga}$.

The maximum deposition age for the Polish Paleoproterozoic metasedimentary sequence is $1.86-1.83 \mathrm{Ga}$. The sequence was metamorphosed to greenshist and amphibolite facies at ca. $1.83 \mathrm{Ga}$.

During the Svecofennian orogeny, the sedimentary basin, or basins, in the area of present-day central Sweden and southern Finland probably extended far to the south. The metasediments of central NE Poland, with a maximum deposition age of $1.86-1.83 \mathrm{Ga}$, are probably equivalent to the younger (Bothnian) sequence in Finland. The age of the early metamorphism possibly decreases to the south and southwest.

It is not possible to identify the source of the Polish sediments with certainty, but the detrital zircon ages bear a close resemblance to the ages of igneous rocks in some nearby terranes, implying that the sediments are of relatively local derivation. The most likely source of the metasediments in Poland, and possibly the rest of the Svecofennian Domain, is the Osnitsk-Mikashevichi Igneous Belt (OMI) on the northwestern margin of the Sarmatia Block, with minor contributions from the Ukrainian Shield.

\section{Acknowledgements}

The study reported here was carried out under the auspices of a collaborative research agreement between the Polish Geological Institute and The Australian National University. The geochemical data and provenance discussion originate from the Ph.D. dissertation of Ewa Krzeminska that was publicly examined in January 2009.

We thank H. Huhma and S. Bogdanova for their very thorough reviews, which resulted in a substantial improvement of the manuscript.

\section{Appendix A. Supplementary data}

Supplementary data associated with this article can be found, in the online version, at doi:10.1016/j.precamres.2009.04.009.

\section{References}

Åhäll, K.-I., Connelly, J.N., 2008. Long-term convergence along SW Fennoscandia: 330 m.y. of Proterozoic crustal growth. Precambrian Research 161, 452-474.

Andersen, T., 2005. Detrital zircons as tracers of sedimentary provenance: limiting conditions from statistics and numerical simulation. Chemical Geology 216 249-270.

Andersson, U.B., Högdahl, K., Sjöstrom, H., Bergman, S., 2006. Multistage growth and reworking of the Paleoproterozoic crust in the Berslagen area, southern Sweden: evidence from U-Pb geochronology. Geological Magazine 143, 679-697.

Bergman, S., Billström, U., Billström, K., Weihed, P., 1996. Geology, tectonic setting and origin of the Paleoproterozoic Boliden $\mathrm{Au}-\mathrm{Cu}-\mathrm{As}$ deposit, Skellefte District, Northern Sweden. Economic Geology 91, 1073-1097.

Bergman, S., Billström, K., Persson, P.-O., Skïold, T., Evins, P., 2006. U-Pb age evidence for repeated Palaeoproterozoic metamorphism and deformation near the Pajala shear zone in the northern Fennoscandian shield. Geologiska Föreningens i Stockholm Förhandlingar 128, 7-20.

Bergman, S., Högdahl, K., Nitronen, M., Ogenhall, E., Sjöstrom, H., Lundqvist, L., Lahtinen, R., 2008. Timing and Palaeoproterozoic intra-orogenic sedimentation in the central Fennoscandian Shield: evidence from detrital zircons in metasandstone. Precambrian Research 161, 231-249.

Beunk, F.F., Page, L.M., Wijbrans, J.R., Barling, J., 1996. Deformational, metamorphic and geochronological constraints from the Loftahammar-Linköping Deformation Zone (LLDZ) in SE Sweden: implications for the development of the Svecofennian orogen. Geologiska Föreningens i Stockholm Förhandlingar 118 A9.

Beunk, F.F., Page, L.M , 2001. Structural evolution of the accretional continenta margin of the Palaeoproterozoic Svecofennian orogen in southern Sweden. Tectonophysics 339, 67-92.

Bhatia, M.R., Crook, K.A., 1986. Trace element characteristics of graywackes and tectonic setting discrimination of sedimentary basins. Contributions to Mineralogy and Petrology 92, 181-193.

Bibikova, E.V., Tugarinov, A.I., Zykov, S.I., 1963. Absolute age determinations of the sedimentary rocks by $\mathrm{U}-\mathrm{Pb}$ method. Geochemistry International N3, 266-283.

Bibikova, E.V., Bogdanova, S.V., Gorbatschev, R., Claesson, S., Kirnozova, T.I., 1995. Isotopic age, nature and structure of the Precambrian crust of Belarus. Stratigraphy and Geological Correlation 3, 591-601.

Bibikova, E.V., Claesson, S., Mansfeld, J., Bogdanova, S.V., Gorbatschev, R., Skridlaite G., Taran, L., 1996. Isotope geochronological evidence of Paleoproterozoic accretion in the western part of the East European Craton. In: Conference Abstracts: EUROBRIDGE Workshop, Oskarshamn, Sweden, pp. 5-6.

Bibikova, E.V., Claesson, S., Stephanyuk, L.M., 2000. The oldest granitoids of the Southwestern Ukrainian Shield (the Bug region): U-Pb and Sm-Nd isotope ages. Report, XIX Seminar “Geology of Magmatic Rocks”, Moscow, April, pp. 25-26 (in Russian).

Billström, K., Weihed, P., 1996. Age and provenance of host rocks and ores in the Paleoproterozoic Skellefte District, Northern Sweden. Economic Geology 91 1054-1072.

Bogdanova, S.V., 2001. Tectonic setting of 1.65-1.4 Ga AMCG magmatism in the Western East European Craton (Western Baltica). In: EUG XI Conference Abstracts 6, p. 769.

Bogdanova, S.V., 2005. The East European Craton: some aspects of the Proterozoic evolution in its south-west. Polish Mineralogical Society Special Papers 26 $18-24$.

Bogdanova, S.V., Bibikova, E., Gorbatchev, R., 1994. Paleoproterozoic U-Pb zircon ages from Belorussia: new tectonic implications for the East European Craton. Precambrian Research 68, 231-240.

Bogdanova, S.V., Page, L.M., Skridlaite, G., Taran, L.N., 2001. Proterozoic tectonothermal history in the western part of the East European Craton: ${ }^{39} \mathrm{Ar} /{ }^{40} \mathrm{Ar}$ geochronological constraints. Tectonophysics 339, 39-66.

Bogdanova, S., Gorbatchev, R., Grad, M., Janik, T., Guterch, A., Kozlowskaya, E., Motuza, G., Skridlaite, G., Starostenko, I., Taran, L., Eurobridge and Polonaise Working Group, 2006. EUROBRIDGE: new inslight into the geodynamic evolution of Eas European craton. In: Gee, D.G., Stephenson, R.A. (Eds.), European Lithosphere Dynamics, vol. 32. Geological Society, London, pp. 599-625 (memoir).

Bostock, H.H., van Breeman, O., 1994. Ages of detrital and metamorphic zircons and monazites from a pre-Taltson magmatic zone basin at the western margin of the Rae Province. Canadian Journal of Earth Sciences 31, 1353-1364.

Claesson, S., 1999. Origin of Paleoproterozoic detritus in the North Atlantic Region. In: EUG-10 Abstracts 4, A07:2B/33:G2

Claesson, S., 1987. Nd isotope data on 1.9-1.2 Ga old basic rocks and metasediments from the Bothnian basin, central Sweden. Precambrian Research 35, 115-140.

Claesson, S., Huhma, H., Kinny, P.D., Williams, I.S., 1993. Svecofennian detrital zircon ages-implications for the Precambrian evolution of the Baltic Shield. Precambrian Research 64, 109-130.

Claesson, S., Lundquist, T., 1995. Origins and ages of Proterozoic granitoids in the Bothnian Basin, central Sweden, isotopic and geochemical constraints. Lithos 36, 115-140. 
Claesson, S., Ryka, W., 1999. Nd model ages of the Precambrian crystalline basement of NE Poland. Between EUROBRIDGE and TESZ, Abstacts. In: Seventh EUROBRIDGE Workshop, Suwalki-Szelment, Poland, pp. 17-18.

Claesson, S., Bogdanova, S.V., Bibikova, E.V., Gorbatschev, R., 2001. Isotopic evidence for Palaeoproterozoic accretion in the basement of the East European Craton. Tectonophysics 339, 1-18.

Claesson, S., Bibikova, E.V., Bogdanova, S.V., Skobelev, V., 2006. Archaean terranes, Palaeoproterozoic reworking and accretion in the Ukrainian Shield, East European Craton, vol. 32, Geological Society, London, pp. 645-654 (memoir).

Claesson, S., Sultan, L., 2008. Constraints on Svecofennian evolution from detrital zircon ages-the Palaeoproterozoic Västervik quartzites. In: Abstract, 33rd International Geological Congress, Oslo, pp. 6-14/8.

Claoué-Long, J.C., Compston, W., Roberts, J., Fanning, C.M., 1995. Two Carboniferous ages: a comparison of SHRIMP zircon dating with conventional zircon ages and ${ }^{40} \mathrm{Ar}-{ }^{39} \mathrm{Ar}$ analysis. Geochronology Time Scales and Global Stratigraphic Correlation, SEPM 54, 3-21 (special publication).

Condie, K.C., 1993. Chemical composition and evolution of the upper continental crust: contrasting results from surface samples and shales. Chemical Geology 104, 1-37.

Cumming, G.L., Richards, G.R., 1975. Ore lead isotope ratios in a continuously changing earth. Earth and Planetary Science Letters 28, 155-171.

Depciuch, T., Lis, J., Sylwestrzak, H., 1975. Wiek izotopowy K-Ar skal podloza krystalicznego połnocno-wschodniej Polski. Kwartalnik Geologiczny 19, 759-779.

Dodson, M.H., Compston, W., Williams, I.S., Wilsom, J.F., 1988. A search for ancient detrital zircons in Zimbabwean sediments. Journal of Geological Society, London $145,977-983$.

Dziedzic, A., 1976. Wyniki badan geochemicznych. w: Ryka (red.) Profile głębokich otworow wiertniczych PIG Jastrzebna 36, 68-75.

EUROBRIDGE'95 Seismic Working Group, 2001. EUROBRIDGE'95: deep seismic profiling within the East European Craton. Tectonophysics 339, 153-175.

Fedo, C.M., Sircombe, K.N., Rainbird, R.H., 2003. Detrital zircon analysis of the sedimentary record. In: Hanchar, J., Hoskin, P.W.O. (Eds.), Zircon, Reviews in Mineralogy and Geochemistry, vol. 53, pp. 277-303.

Floyd, P.A., Shail, R., Leveridge, B.E., Franke, W., 1991. Geochemistry and provenance study of Rhenohercynian synorogenic sandstones; implications for tectonic environment discrimination. In: Morton, A.C., Todd, S.P., Houghton, D.W. (Eds.), Developments in Sedimentary Provenance Studies, vol. 57. Geological Society, London, pp. 173-185 (special publication).

Gorbatschev, R, 2004. The Transscandinavian Igneous Belt-introduction and background. In: Högdahl, K. (Ed.), The Transscandinavian Igneous Belt (TIB) in Sweden: A Review of its Character and Evolution, vol. 37. Geological Survey of Finland, pp. 9-13 (special paper).

Gorbatschev, R., Bogdanova, S., 1993. Frontiers in the Baltic Shield. Precambrian Research 64, 3-21.

Gaal, G., Gorbatschev, R., 1987. An outline of Precambrian evolution of the Baltic Shield. Precambrian Research 35, 15-52.

Henry, D.J., Guidotti, C.V., Thomson, J.A., 2005. The Ti-saturation surface for lowto-medium pressure metapelitic biotite: implications for geothermometry and Ti-substitution mechanisms. American Mineralogist 90, 316-328.

Herron, M.M., 1988. Geochemical classification of terrigenous sands and shales from core or log data. Journal of Sedimentary Petrology 58, 820-829.

Hietanen, A., 1975. Generation of potassium-poor magmas in the northern Sierra Nevada and the Svecofennian of Finland. Journal of Research of the U.S. Geological Survey 3, 631-645.

Huhma, H., 1986. Sm-Nd, U-Pb, Pb-Pb isotopic evidence for the origin of the Early Proterozoic Svecokarelian crust in Finland. Geological Survey of Finland Bulletin 337, 1-48.

Huhma, H., Claesson, S., Kinny, P.D., Williams, I.S., 1991. The growth of Early Proterozoic crust: new evidence from Svecofennian detrital zircons. Terra Nova 3, 175-178.

Högdahl, K., Andersson, U.B., Eklund, O., 2004. The Transscandinavian Igneous Belt (TIB) in Sweden: a review of its character and evolution. Geological Survey of Finland 37, 1-125 (special paper)

Högdahl, K., Sjöström, H., 2006. The Hassela Shear zone-a link between migmatites and the contemporaneous Ljusdal Batholith. Geological Survey of Finland Bulletin 1, 57 (special issue).

Högdahl, K., Sjöström, H., Andersson, U.B., Ahl, M., 2008. Continental margin magmatism and migmatisation in the west-central Fennoscandian Shield. Lithos 102, 435-459.

Kähkönen, Y., Leveinen, J., 1994. Geochemistry of metasedimentary rocks of the Palaeoproterozoic Tampere schist belt, southern Finland. In: Nironen, M., Kähkönen, Y. (Eds.), Geochemistry of Proterozoic Supracrustal Rocks in Finland, vol. 19. Geological Survey of Finland, pp. 117-136 (special paper).

Kilpeläinen, T., Korikovsky, S., Korsman, K., Nironen, M., 1994. Tectono-metamorphic evolution in the Tampere-Vammala area. In: Pajunen, M. (Ed.), High Temperature-Low Pressure Metamorphism and Deep Crustal Structures, vol. 37. Geological Survey of Finland, pp. 27-34 (Guide).

Korja, A., Lahtinen, R., Nironen, M., 2006. The Svecofennian orogen: a collage of microcontinents and island arcs. In: Gee, D.G., Stephenson, R.A. (Eds.), European Lithosphere Dynamics, vol. 32. Geological Society, London, pp. 561-578 (memoir).

Korsman, K., Hölttä, P., Hautala, T., Wasenius, P., 1984. Metamorphism as an indicator of evolution and structure of the crust in eastern Finland. Geological Survey of Finland Bulletin 328, 1-40.

Korsman, K., Niemelä, R., Wasenius, P., 1988. Multistage evolution of the Proterozoic crust in the Savo schist belt, eastern Finland. In: Korsman, K. (ed.), Tectono- metamorphic Evolution of the Raahe-Ladoga Zone. Geological Survey of Finland, Bulletin 343, 89-96.

Krzemińska, E., Williams, I.S., Wiszniewska, J., 2005. A Late Paleoproterozoic $(1.80 \mathrm{Ga})$ subduction-related mafic igneous suite from Lomza, NE Poland. Terra Nova 17, 442-449.

Krzemińska, E., Wiszniewska, J., Williams, I.S., 2006a. Wczesnokarboński wiek intruzji platformowych w podłożu krystalicznym NE Polski. Przeglad Geologiczny 54, 1093-1098.

Krzemińska, E., Wiszniewska, J., Williams, I.S., 2006b. Rewizja wieku “najstarszych” skał w podłożu krystalicznym północno-wschodniej Polski. Przegląd Geologiczny 54, 967-973.

Krzemińska, E., Wiszniewska, J., Williams, I.S., Dörr, W., 2007. Late Paleoproterozoic arc-related granites from the Mazowsze domain, NE Poland. Granitoids in Poland. In: Kozłowski, A., Wiszniewska, J. (Eds.), AM Monograph. Polish Geological Institute and Warsaw University, Warsaw, pp. 41-56.

Krzemińska, E., Wiszniewska, J., 2007. Swekofeńskie korzenie "masywu" mazowieckiego. Przegląd Geologiczny 55, 294-295.

Kubicki, S., Ryka, W., 1982. Geological Atlas of Crystalline Basement in the Polish Part of the East-European Platform. Polish Geological Institute, Warsaw.

Kumpulainen, R.A., Mansfeld, J., Sundblad, K., Neymark, L., Bergman, T., 1996. Stratigraphy, age and $\mathrm{Sm}-\mathrm{Nd}$ isotope systematics of the country rocks to $\mathrm{Zn}-\mathrm{Pb}$ sulfide deposits, Åmmerberg district, Sweden. Economic Geology 91, 1009-1021.

Lahtinen, R., 1994. Crustal evolution of the Svecofennian and Karelian domains during 2.1-1.79 Ga, with special emphasis on the geochemistry and origin of 1.93-1.91 Ga gneissic tonalites and associated supracrustal rocks in the Rautalampi area, central Finland. Geological Survey of Finland Bulletin 378, 1-128.

Lahtinen, R., 1996. Geochemistry of Palaeoproterozoic supracrustal and plutonic rocks in the Tampere-Hämeenlinna area, southern Finland. Geological Survey of Finland Bulletin 389, 1-113.

Lahtinen, R., 2000. Arechean-Proterozoic transition: geochemistry, provenance and tectonic setting of metasedimentary rocks in central Fennoscandian Shield, Finland. Precambrian Research 104, 147-174.

Lahtinen, R., Huhma, H., Kousa, J., 2002. Contrasting source components of the Paleoproterozoic Svecofennian metasediments: detrial zircon U-Pb, Sm-Nd and geochemical data. Precambrian Research 116, 81-109.

Lobach-Zuchenko, S.B., Chekulaev, V.P., Sergeyev, S.A., Levchenkov, O.A., Kornilov, I.N., 1993. Archean rocks from SE Karelia (Karelian greenstone terranes). Precambrian Research 62, 375-388.

Mansfeld, J., 2001. Age and $\varepsilon_{\mathrm{Nd}}$ constraints on the Palaeoproterozoic tectonic evolution in the Baltic-Sea region. Tectonophysics 339, 135-151.

Marfin, S., Motuza, G., Mitrofanov, F.P., Drubetzkoi, E.R., Nemchin, A.A., 1987. New determinations of radiogenic age of rocks from crystalline basement of Lithuania. Geologija 8, 3-9.

Martin, H., Smithies, R.H., Rapp, R., Moyen, J.-F., Champion, D., 2005. An overview of adakite, tonalite-trondhjemite-granodiorite (TTG) and sanukitoid: relationships and some implications for crustal evolution. Lithos 79, 1-24.

Martin, H., Moyen, J.-F., 2005. The Archaean-Proterozoic transition: sanukitoid and Closepet type magmatism. Mineralogical Society of Poland Special Papers 26, 62-66.

Möller, C., Andersson, J., Lundqvist, I., Hellström, F., 2007. Linking deformation, migmatite formation and zircon $\mathrm{U}-\mathrm{Pb}$ geochronology in polymetamorphic othogneisses, Sveconorwegian Province, Sweden. Journal of Metamorphic Geology 25, 727-750.

Motuza, G., 2005. Structure and formation of the crystalline crust in Lithuania. Mineralogical Society of Poland Special Paper 26, 70-80.

Mouri, H., Korsman, K., Huhma, H., 1999. Tectono-metamorphic evolution and timing of the melting processes in the Swecofennian tonalite-trondhjemite migmatite belt: example from Luopiinen, Tampere area, S Finland. Bulletin of the Geological Society of Finland 71, 31-56.

McLennan, S.M., 1989. Rare earth elements in sedimentary rocks: influence of provenance and sedimentary processes. Reviews in Mineralogy 21, 169-200.

McLennan, S.M., Taylor, S.R., McCulloch, M.T., Maynard, J.B., 1990. Geochemical and $\mathrm{Nd}-\mathrm{Sr}$ isotopic composition of deep-sea turbidites: crustal evolution and plate tectonic associations. Geochimica et Cosmochimica Acta 54, 2015-2050.

McLennan, S.M., Hemming, S., McDaniel, D.K., Hannson, G.N., 1993. Geochemical approaches to sedimentation, provenance and tectonics. Geological Society of America Special Paper 284, 21-40.

Mutanen, T., Huhma, H., 2003. The 3.5 Ga Siurua trondhjemite gneiss in the Archean Pudasjärvi Granulite Belt, northern Finland. Bulletin of the Geological Society of Finland 75, 51-68.

Nironen, M., 1997. The Svecofennian Orogen: a tectonic model. Precambrian Research 86, 21-44.

Nesbit, H.W., Young, G.M., 1982. Early Proterozoic climates and plate motion inferred from major element chemistry of latities. Nature 299, 715-717.

Nutman, A.P., Kalsbeek, K., Marker, M., van Gool, J.A.M., Bridgewater, D., 1999. U-Pb zircon ages of Kangamiut dykes and detrital zircons in metasediments in the Palaeoproterozoic Nagssugtoqidian Orogen (West Greenland). Clues to the precollisional history of the orogen. Precambrian Research 93, 87-104.

Ojakangas, R.W., 1986. An early Proterozoic greywacke-shale turbidite sequence: the Tampere schist belt, southwestern Finland. Bulletin of the Geological Society of Finland 58, 241-261.

Park, A.F., 1985. Accretion tectonism in the Proterozoic Svecokarelides of the Baltic Shield. Geology 13, 725-729.

Patchett, P.J., Todt, U., Gorbatchev, R., 1987. Origin of continental crust 1.9-1.7 Ga: Nd isotopes in the Svecofennian orogenic terranes of Sweden. Precambrian Research $35,145-160$. 
Puura, V., Huhma, H., 1993. Palaeoproterozoic age of the East Baltic granulite crust. Precambrian Research 64, 289-294.

Rollinson, H., 1994. Using geochemical data: evolution, presentation, interpretation. In: Longman Geochemical Series. Longman/J. Wiley \& Son, UK/New York, pp. $1-352$.

Roser, B.P., Korsh, R.J., 1986. Determination of tectonic setting of sandstonemudstone suites using $\mathrm{SiO}_{2}$ content and $\mathrm{K}_{2} \mathrm{O} / \mathrm{Na}_{2} \mathrm{O}$ ratio. Journal of Geology 94, 635-650.

Rutland, R.W.R., Williams, I.S., Korsman, K., 2004. Pre-1.91 Ga deformation and metamorphism in the Palaeoproterozoic Vammala Migmatite Belt, southern Finland, and implications for Svecofennian tectonics. Bulletin of the Geological Society of Finland 76, 93-140.

Ryka, W., 1976. Wyniki badan petrograficznych skał podloza krystalicznego. Profile głębokich otworów wiertniczych PIG Jastrzebna 36, 21-46.

Ryka, W., 1984. Precambrian evolution of the East European Platform in Poland. Biuletyn Instytutu Geologicznego 347, 17-28.

Ryka, W., 1998. Geologic position of the Suwałki Anorthosite Massif. Prace Państwowego Instytutu Geologicznego 161, 19-26.

Sambridge, M., Compston, W., 1994. Mixture modeling of multi-component data sets with application to ion-probe zircon ages. Earth and Planetary Science Letters $128,373-390$.

Sederholm, J.J., 1897. Über eine archäische Sedimentformation im südwestlichen Finland und ihre Bedeutung für die Erklärung der Entstehungsweise des Grundgebirges. Bulletin Commission Géologique Finlande 6, 1-254

Sergeyev, S.A., Bibikova, Ye.V., Levchenkov, O.A., Lobach-Zhuchenko, S.G., Yakovleva, S.Z., Ovchinnikova, G.V., Neymark, L.A., Komarov, A.N., Gorkhovskiy, B.M., 1990. Isotope geochronology of the Vodlozero gneiss complex. Geochemistry International 8, 65-74.

Shaw, D.M., 1968. The review of K-Rb fractionation trends by covariance analysis. Geochimica et Cosmochimica Acta 32, 573-602.

Shcherbak, N.P., Artemenko, G.V., Skobelev, V.M., Stepanyuk, L.M., Ponomarenko, O.M., 2002. Geochronology of the Precambrian of the Ukrainian Shield on the basis of the "Reference" isotope data. Minerological Journal (Ukraine) 24, 87-110.

Shumlyanskyy, L.L., Bogdanova, S.V., Tsymbal, S., 2006. Heterogeneity of the Proterozoic lower crust and lithospheric mantle beneath the north-western Ukrainian Shield: implication of trace element and isotopic geochemistries of mafic intrusions. Geophysical Research Abstracts 8, 00647.

Skiöld, T., Öhlander, B., Markula, H., Winderfald, L., Claesson, S., 1993. Chronology of Proterozoic orogenic processes at the Archean continental margin in northern Sweden. Precambrian Research 64, 225-238.

Skiöld, T., Rutland, R.W.R., 2006. Successive $\sim 1.94$ Ga plutonism and $\sim 1.92$ Ga deformation and metamorphism south of the Skellefte district, northern Sweden. Substantiation of the marginal basin accretion hypothesis of Svecofennian evolution. Precambrian Research 148, 181-204.

Skridlaite, G., Krzemińska, E., Wiszniewska, J., 2007. Proterozoiczny łuk wysp-interpretacja osadowo-wulkanicznej formacji skał z podłoża krystalicznego południowej Litwy i Północno-wschodniej Polski. Przegląd geologiczny 55, 305-306.

Skridlaite, G., Motuza, G., 2001. Precambrian domains in Lithuania: evidence of terrane tectonics. Tectonophysics 339, 113-133.

Slabunov, A.I., Lobach-Zhuchenko, S.B., Bibikova, E.V., Sorjonen-Ward, P., Balagansky, V.V., Volodichev, O.I., Shchipansky, A.A., Svetov, S.A., Cherkulaev, V.P., Arestova, N.A., Stepanov, V.S., 2006. The Archean nucleus of Fennoscandian (Baltic) Shield. In: Gee, D.G., Stephenson, R.A. (Eds.), European Lithosphere Dynamics, vol. 32. Geological Society, London, pp. 627-644 (memoir).

Soesoo, A., Puura, V., Kirs, J., Petersell, V., Niin, M., All, T., 2004. Outlines of the Precambrian basement of Estonia. Proceedings of the Estonian Academy of Sciences 53, 149-164.
Steiger, R.H., Jäger, E., 1977. Subcommission on geochronology: convention on the use of decay constants in geo- and cosmochronology. Earth and Planetary Science Letters 36, 359-362.

Student, 1908. The probable error of a mean. Biometrika 6, 1-25.

Sultan, L., Claesson, S., Plink-Björklund, P., 2005. Proterozoic and Archean ages of detrital zircon from the Palaeoproterozoic Västrvik Basin. SE Sweden: Implications for provenance and timing of deposition. Geologiska Föreningens Stockholm Förhandlingar 127, 17-24.

Sun, S.S., McDonough, W.F., 1989. Chemical and isotopic systematics of oceanic basalts: implications for mantle composition and processes. In: Saunders, A.D. Norry, M.J. (Eds.), Magmatism in the Ocean Basins, vol. 42. Geological Society, London, pp. 313-345 (special publication).

Taran, L.N., 2001. Distribution of the Okolovo unit in the crystalline basement of Belarus. Litasfera 1, 72-81.

Taran, L.N., Bogdanova, S.V., 2003. Metamorphism of Paleoproterozoic paragneisses in the Belarus-Podlyasie Granulite Belt: prograde-retrograde evolution. Petrologija 11, 425-442 (in Russian).

Taylor, S.R., McLennan, S.M., 1985. The Continental Crust: Its Composition and Evolution. Blackwell, Oxford, $312 \mathrm{pp}$.

Torsvik, T.H., Smethurst, M.A., Meert, J.G., Van der Voo, R., McKerrow, W.S., Brasier M.D., Sturte, B.A., Walderhaug, H.J., 1996. Continental break-up and collision in the Neoproterozoic and Palaeozoic-a tale of Baltica and Laurentia. Earth-Science Reviews 40, 229-258.

Tuisku, P., Huhma, H., 2006. Evolution of migmatitic granulite complexes: implications from Lapland granulite belt. Part II. Isotopic dating. Bulletin of the Geological Society of Finland 78, 143-175.

Van de Kamp, P.C., Leake, B.E., 1995. Petrology and geochemistry of siliciclastic rocks of mixed feldspathic and ophiolitic provenance in the Northern Apennines, Italy. Chemical Geology 122, 1-20.

Vermeesh, P., 2004. How many grains are needed for a provenance study? Earth and Planetary Science Letters 224, 441-451.

Welin, E., Christiansson, K., Kähr, A.-M., 1993. Isotopic investigations of metasedimentary and igneous rocks in the Palaeoproterozoic Bothnian basin central Sweden. Geologiska Föreningens i Stockholm Förhandlingar 115 285-296.

Williams, I.S., Claesson, S., 1987. Isotopic evidence for the Precambrian provenance and Caledonian metamorphism of high grade paragneisses from the Seve Nappes, Scandinavian Caledonides. II. Ion microprobe zircon U-Th-Pb. Contributions to Mineralogy and Petrology 97, 205-217.

Williams, I.S., Rutland, R.W.R., Kousa, J., 2008. A regional $1.92 \mathrm{Ga}$ tectonothermal episode in Ostrobothnia, Finland: implications for models of Svecofennian accretion. Precambrian Research 165, 15-36.

Wiszniewska, J., Claesson, S., Stein, H.J., Vander Auwera, J., Duchesne, J.C., 2002. The north-eastern Polish anorthosite massifs: petrological, geochemical and isotopic evidence for a crustal derivation. Terra Nova 14, 451-460.

Wiszniewska, J., Krzemińska, E., Williams, I.S., 2006. Geochemical and geochronological correlation of Svecofennian metasedimentary complexes from NE Poland, central Finland and Sweden. Geophysical Research Abstracts 8, 10227.

Wiszniewska, J., Krzemińska, E., Dörr, W., 2007. Evidence of arc-related Svecofennian magmatic activity in the southwestern margin of the East European Craton in Poland. Gondwana Research 12, 268-278.

Wolkowicz, K., 1996. Wyniki badań geochemicznych. In: Ryka, W. (Ed.), Profile głębokich otworów wiertniczych PIG Mońki IG-1, IG-2, vol. 84, pp. 37-56.

Wybraniec, S., 1999. Transformation and visualization of potential field data. Polish Geological Institute 1, 1-88 (special paper).

Zhao, G., Cawood, P.A., Wilde, S.A., Sun, M., 2002. Review of global 2.1-1. 8 Ga orogens: implications for a pre-Rodinia supercontinent. Earth-Science Reviews 59 , 125-162. 